\title{
Centennial-scale variability of the Southern Hemisphere westerly wind belt in the eastern Pacific over the past two millennia
}

\author{
B. G. Koffman ${ }^{1,2,3}$, K. J. Kreutz ${ }^{1,2}$, D. J. Breton ${ }^{2,4,}$, E. J. Kane ${ }^{1}$, D. A. Winski ${ }^{1,2,{ }^{* *}}$, S. D. Birkel ${ }^{2}$, A. V. Kurbatov ${ }^{1,2}$, \\ and M. J. Handley ${ }^{2}$ \\ ${ }^{1}$ School of Earth and Climate Sciences, University of Maine, 5790 Bryand Global Sciences Center, Orono, ME 04469, USA \\ ${ }^{2}$ Climate Change Institute, University of Maine, 300 Bryand Global Sciences Center, Orono, ME 04469, USA \\ ${ }^{3}$ Lamont-Doherty Earth Observatory of Columbia University, 61 Route 9W, Palisades, NY 10964, USA \\ ${ }^{4}$ Department of Physics and Astronomy, Bennett Hall, University of Maine, Orono, ME 04469, USA \\ * currently at: USACE-Cold Regions Research and Engineering Laboratory, 72 Lyme Road, Hanover, NH, 03755, USA \\ ** currently at: Department of Earth Sciences, Dartmouth College, HB6105 Fairchild Hall, Hanover, NH 03755, USA
}

Correspondence to: B. G. Koffman (bkoffman@1deo.columbia.edu)

Received: 4 May 2013 - Published in Clim. Past Discuss.: 13 June 2013

Revised: 7 March 2014 - Accepted: 25 April 2014 - Published: 11 June 2014

\begin{abstract}
We present the first high-resolution (sub-annual) dust particle data set from West Antarctica, developed from the West Antarctic Ice Sheet (WAIS) Divide deep ice core $\left(79.468^{\circ} \mathrm{S}, 112.086^{\circ} \mathrm{W}\right)$, and use it to reconstruct changes in atmospheric circulation over the past 2400 years. We find a background dust flux of $\sim 4 \mathrm{mg} \mathrm{m}^{-2}$ year $^{-1}$ and a mode particle size of 5-8 $\mu \mathrm{m}$ diameter. Through comparing the WAIS Divide record with other Antarctic ice core particle records, we observe that coastal and lower-elevation sites have higher dust fluxes and coarser particle size distributions (PSDs) than sites on the East Antarctic plateau, suggesting input from local dust sources at these lower-elevation sites. In order to explore the use of the WAIS Divide dust PSD as a proxy for past atmospheric circulation, we make quantitative comparisons between both mid-latitude zonal wind speed and West Antarctic meridional wind speed and the dust size record, finding significant positive interannual relationships. We find that the dust PSD is related to midlatitude zonal wind speed via cyclonic activity in the Amundsen Sea region. Using our PSD record, and through comparison with spatially distributed climate reconstructions from the Southern Hemisphere ( $\mathrm{SH}$ ) middle and high latitudes, we infer that the $\mathrm{SH}$ westerlies occupied a more southerly position from circa 1050 to $1400 \mathrm{CE}$ (Common Era), coinciding with the Medieval Climate Anomaly (MCA). Subsequently, at ca. $1430 \mathrm{CE}$, the wind belt shifted equatorward, where it remained until the mid-to-late twentieth century. We find co-
\end{abstract}

variability between reconstructions of El Niño-Southern Oscillation (ENSO) and the mid-latitude westerly winds in the eastern Pacific, suggesting that centennial-scale circulation changes in this region are strongly influenced by the tropical Pacific. Further, we observe increased coarse particle deposition over the past 50 years, consistent with observations that the $\mathrm{SH}$ westerlies have been shifting southward and intensifying in recent decades.

\section{Introduction}

The Southern Hemisphere (SH) westerly winds (SWW) are a major driver of regional and global climate (Thompson and Solomon, 2002; Toggweiler et al., 2006). The SWW form a strong, zonally symmetric wind belt, centered at approximately $50^{\circ} \mathrm{S}$, that circles the Antarctic continent (Fig. 1a). The SWW carry moisture, soil dust, volcanic ash, and other aerosols. A growing number of publications point to the SWW as the primary control on atmospheric $\mathrm{CO}_{2}$ variability on glacial-interglacial timescales because wind stress on the Southern Ocean controls the rate of deep water ventilation around Antarctica (Toggweiler et al., 2006; Anderson et al., 2009; Burke and Robinson, 2012). The Southern Ocean is the only region in the world's oceans where water of 2 $3 \mathrm{~km}$ depth can upwell to the surface, coming into direct contact with the atmosphere (Russell et al., 2006). The rate of 
upwelling is governed by the strength of the Antarctic Circumpolar Current (ACC), which is driven by the SWW. The position of the SWW belt relative to the ACC determines the winds' influence on ventilation of these deep, $\mathrm{CO}_{2}$-rich waters (Toggweiler et al., 2006). During the last glacial termination, a climate modeling study suggests that a latitudinal shift of $3-4^{\circ}$ toward Antarctica would significantly have increased the ventilation of deep water, resulting in $\mathrm{CO}_{2}-$ induced warming (Russell et al., 2006). A proposed mechanism for such shifts is that cold temperatures in the Northern Hemisphere (NH) push earth's thermal equator southward, displacing the SWW poleward (Toggweiler et al., 2006; Denton et al., 2010). Such shifts in the SWW prior to climate warming events are corroborated by a new dust record from the EPICA Dome C ice core (East Antarctica; EPICA: European Project for Ice Coring in Antarctica; Lambert et al., 2012). Sharp declines in dust deposition preceded changes in temperature during glacial terminations and Antarctic isotopic maxima over the past 800 thousand years (ka), suggesting that rapid shifts in the SWW may have led to reductions in dust mobilization from Patagonian sources, while simultaneously increasing rates of deep ocean upwelling, leading to atmospheric warming (Lambert et al., 2012). Rapid changes in wind gustiness, driven by meridional temperature gradients, may also have affected dust mobilization (McGee et al., 2010). In addition, the SWW also are thought to play a major role in governing the rate of Agulhas leakage in the South Atlantic, thereby directly affecting the Atlantic Meridional Overturning Circulation (De Deckker et al., 2012). Therefore, through multiple mechanisms, the SWW exert a strong control on global climate.

The SWW also influence ocean-atmosphere $\mathrm{CO}_{2}$ fluxes on shorter timescales (Takahashi et al., 2002). Indeed, changes in the position and strength of the SWW may be the main driver of $\mathrm{CO}_{2}$ variability during the Holocene (Moreno et al., 2009, 2010). Although different proxies for SWW intensity and/or position yield potentially conflicting patterns of change during the early to mid-Holocene (Lamy et al., 2010; Björck et al., 2012), it seems apparent that the SWW shifted in response to larger-scale climate changes, most likely driven by changes in radiative forcing (Renssen et al., 2005; Varma et al., 2012). During the late Holocene, records from around the SH suggest a transition from zonally symmetric to zonally asymmetric patterns of SWW variability, a change attributed to increased influence of high-frequency El Niño-Southern Oscillation (ENSO) events (Fletcher and Moreno, 2011, 2012). Currently the SWW appear to be intensifying and shifting poleward, largely due to the effect of stratospheric ozone depletion in the Antarctic region, with a lesser effect induced by greenhouse gas forcing (Thompson and Solomon, 2002; Arblaster and Meehl, 2006; Thompson et al., 2011; Lee and Feldstein, 2013). These changes in the winds, which are occurring primarily in austral summer and autumn (Thompson and Solomon, 2002), have increased the ventilation rate of Southern Ocean waters in past decades, a trend that is likely to continue (Waugh et al., 2013). Enhanced upwelling of $\mathrm{CO}_{2}$-rich deep waters has led to increased surface ocean $\mathrm{CO}_{2}$ concentrations, while at the same time reducing anthropogenic carbon uptake (Lenton et al., 2009, 2012). Although ongoing changes in ozone and greenhouse gas concentrations are driving the SWWSouthern Ocean system into a non-analog state (Mayewski et al., 2009; Turner et al., 2009), it is important to understand how the SWW varied in strength and position in the past, in response to natural forcings. In particular, SWW variability on decadal to centennial timescales remains poorly understood. What mechanisms cause the SWW to shift position and/or intensity? Do the winds respond to different forcings on different timescales? And how might these natural forcings change in response to ongoing anthropogenic warming? The late Holocene contains intervals of significant climate variability prior to the industrial era, namely the Medieval Climate Anomaly (MCA, ca. 950-1250 CE) and Little Ice Age (LIA, ca. 1400-1850 CE) (e.g., Mann et al., 2008), and is thus an important period during which to address these questions. While these intervals have been defined largely by temperature anomalies in the NH (e.g., Mann et al., 2008, 2009), it is important to understand whether and how these signals have been transmitted to the $\mathrm{SH}$, and how the timing of events has varied regionally.

Because of the dynamic response of dust emissions to climate forcing, high-resolution terrestrial dust archives, such as ice cores, can be used to understand the timing and mechanisms of past climate changes (Mayewski et al., 1994, 2009; Legrand and Mayewski, 1997). Ice core records have shown a tight, nonlinear coupling between dust flux and Antarctic regional temperature on glacial/interglacial timescales (Steffensen, 1997; Petit et al., 1999; Wolff et al., 2006; Fischer et al., 2007; Lambert et al., 2008), a relationship that appears to have held over the past 4 million years (Martinez-Garcia et al., 2011). Observed changes in Antarctic dust flux have been linked to glacier activity (Sugden et al., 2009) and anthropogenic land-use changes (McConnell et al., 2007) in dust source regions, as well as to changes in atmospheric circulation and the intensity of the hydrological cycle (Petit et al., 1999; Fischer et al., 2007; Lambert et al., 2008, 2012; Mayewski et al., 2013). In addition, ice core records of aerosol iron deposition have been used to assess the potential impact of atmospheric dust on fertilizing the Southern Ocean (Edwards et al., 2006; Gaspari et al., 2006), the largest iron-limited region of the world's oceans (Turner and Hunter, 2001). In addition to the information contained in dust flux records, particle size data can be used to understand the proximity of dust source(s) and the strength of atmospheric transport (e.g., Bory et al., 2010; Kok, 2011a). If the geographical source remains constant, the size distribution of particles can be used as an indicator of past changes in wind strength, providing valuable information that cannot be obtained through looking at chemical dust proxies (such as $\mathrm{Al}, \mathrm{Ce}$, and non- 

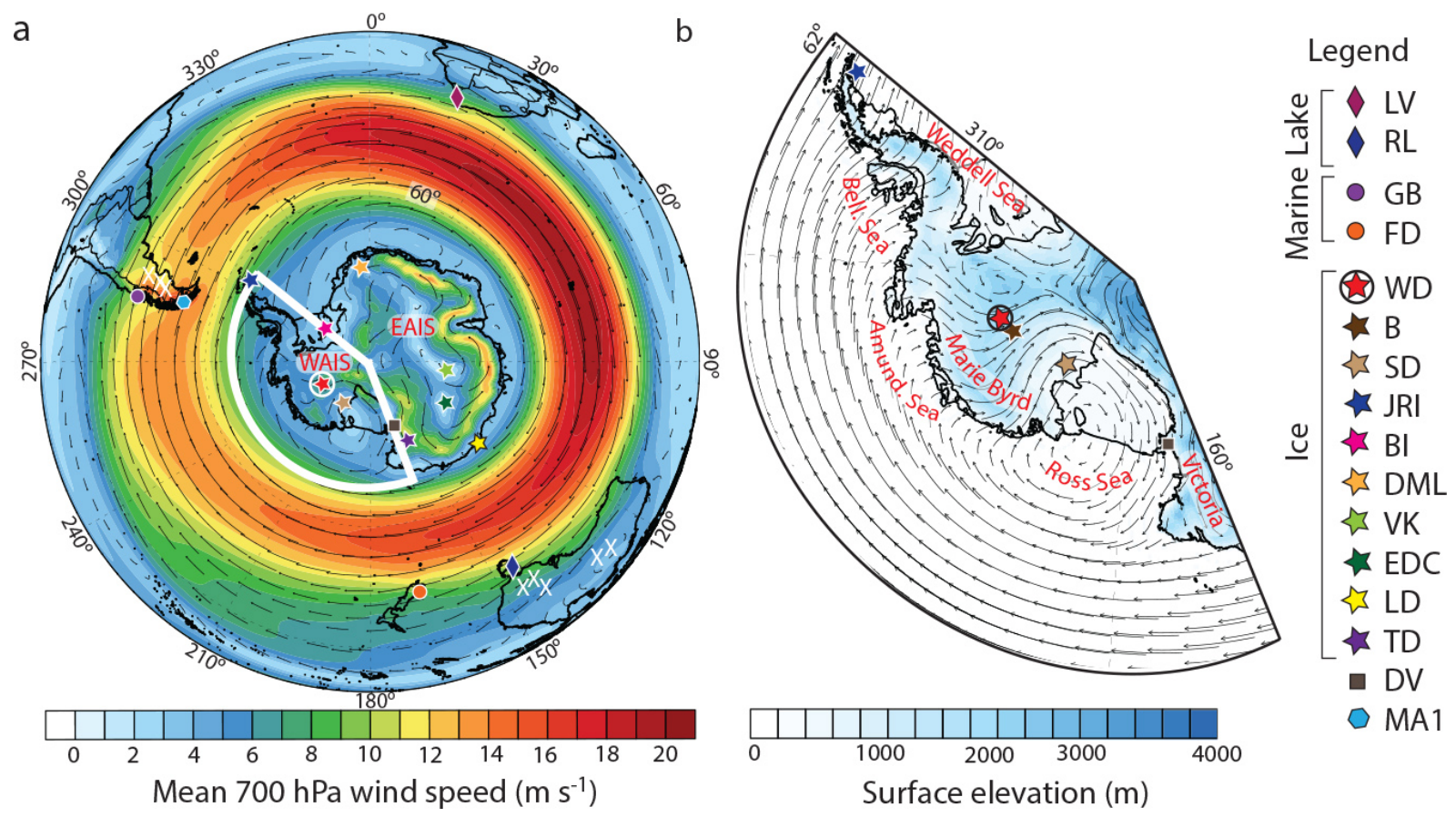

Figure 1. (a) Map of the Southern Hemisphere showing mean (1979-2010) annual wind speed (colors) and direction (vectors) at 700 hPa from ERA-Interim reanalysis data, major SH dust sources (white Xs), and locations of sites discussed in the text, as indicated (lake cores: LV: Lake Verlorenvlei; RL: Rebecca Lagoon. Marine cores: GB: GeoB 3313-1; FD: Fiordland. Ice cores: WD: WAIS Divide; B: Byrd; SD: Siple Dome; JRI: James Ross Island; BI: Berkner Island; DML: EPICA Dronning Maud Land; VK: Vostok; EDC: EPICA Dome C; LD: Law Dome; TD: Talos Dome. DV: Dry Valleys. MA1: Marcelo Arévalo Stalagmite; WAIS: West Antarctic Ice Sheet; EAIS: East Antarctic Ice Sheet; Victoria: Victoria Land; Marie Byrd: Marie Byrd Land). (b) Map of the WAIS region showing elevation (blue shading), annual average $700 \mathrm{hPa}$ wind vectors from ERA-Interim reanalysis data, and site locations, as indicated.

sea salt Ca, nssCa) alone (Delmonte et al., 2002, 2005; Kok, 2011a).

In this paper, we present results from microparticle analysis of the upper $577 \mathrm{~m}$ (2400 years) of the West Antarctic Ice Sheet (WAIS) Divide deep ice core. The drill site is located roughly between the Antarctic Peninsula and the East Antarctic Ice Sheet (EAIS), in a high-accumulation area, allowing development of a continuous, highly temporally resolved dust deposition record $\left(\sim 10-20\right.$ samples year $\left.^{-1}\right)$. We present dust flux, concentration, and size distribution records, and compare them to late Holocene data from other Antarctic ice cores. In addition, we present automatic weather station (AWS) and ERA-Interim reanalysis data in order to characterize local- and regional-scale atmospheric circulation. We use correlations with reanalysis zonal wind speed to calibrate the dust record over the period 1979-2002, and argue that the coarse dust particle fraction is driven by variability in SWW intensity via cyclonic storm activity in the AmundsenBellingshausen Sea region.

A significant challenge in reconstructing past SWW behavior is to deconvolve changes in the latitudinal position of the SWW belt from independent changes in wind intensity. We believe that by synthesizing records spanning the latitudinal range of SWW influence, we can make progress toward this goal. Specifically, our aim is to understand how the latitudinal position of the SWW varied on decadal to centennial timescales during the late Holocene. We use our coarse particle record in conjunction with paleohydrological reconstructions from the $\mathrm{SH}$ mid-latitudes to suggest that the SWW occupied a more southerly position from 1050 to $1400 \mathrm{CE}$ (Common Era), and shifted to a more northerly position around $1430 \mathrm{CE}$, remaining there until the mid-20th century. Our assessment of potential mechanisms suggests that the tropical Pacific played an important role in driving SWW changes in the eastern Pacific on centennial timescales during the late Holocene.

\section{Methods}

\subsection{WAIS Divide ice core melting and analysis}

The West Antarctic Ice Sheet (WAIS) Divide ice core was drilled to a depth of $3405 \mathrm{~m}$ in central West Antarctica $\left(79.468^{\circ} \mathrm{S}, 112.086^{\circ} \mathrm{W} ; 1766 \mathrm{~m}\right.$ a.s.l.; Fig. 1). The average accumulation rate of $0.207 \mathrm{~m}_{\text {weq }} \mathrm{a}^{-1}$ (Banta et al., 2008) is sufficient for detection of well-preserved annual layers well below the depths analyzed here. We melted the upper $577 \mathrm{~m}$ of the deep ice core, WDC06A, using a continuous ice core 
melting system with both continuous flow-through analysis (CFA) and discrete sampling for geochemical and microparticle analysis (Breton et al., 2012). Prior to melting, core ends and breaks were scraped under a high-efficiency particulate absorption (HEPA) hood using a clean ceramic blade to reduce possible contamination from drilling fluid and other sources. Despite this mechanical cleaning, we observed that core breaks tended to introduce particulate contamination into the ice. Therefore, during our data processing procedure, we removed dust concentration peaks that were associated with observed breaks in the ice core.

The ice core meltwater was analyzed for microparticle concentrations using a CFA laser particle detector (LPD; Klotz Abakus), and for electrolytic conductivity using a CFA conductivity cell (Amber Science). Depth co-registration for both data sets was achieved using a weight and rotary encoder and our sample-tracking algorithm, achieving a depth uncertainty of $\pm 1 \mathrm{~mm}$. The effective depth resolution obtained by our system, limited by signal dispersion, is $1.0 \mathrm{~cm}$ in glacial ice and $\sim 2 \mathrm{~cm}$ in low-density firn, which is equivalent to $\sim 10-20$ samples year $^{-1}$ for the late Holocene core analyzed here (Breton et al., 2012). Raw time-series data were filtered using a low-pass filter based on the PL64 filter, with a time step of 1.64 days and a cutoff of either 12 or 252 months ( 1 or 21 years; G. Gerbi, personal communication, 2011).

Using the LPD, we analyzed insoluble particles in 31 size channels, spanning 1.0 to $15.0 \mu \mathrm{m}$ diameter, and calculated particle concentrations using directly measured flow rates. The LPD was calibrated with Antarctic snow samples using a Coulter counter, as described by Ruth et al. (2003). By calibrating the instrument using environmental samples (rather than latex standards), we attempted to avoid some of the size calibration issues described by Lambert et al. (2012), namely, that spherical particles are a poor proxy for the range of shapes exhibited by insoluble dust particles. After calibration, we tested the LPD using commercial size and concentration standards, and found that it accurately measured latex spheres of $1,2,5$ and $10 \mu \mathrm{m}$ diameter and successfully registered the orders-of-magnitude differences in concentration that we tested (not shown). In addition, we melted and analyzed six pairs of replicate ice "sticks" cut parallel to the same one-meter section of ice core. We melted these "sticks" in antiparallel orientations to evaluate signal fidelity measured using our CFA instruments. Results from replicate core analysis show excellent reproducibility in both signal depth and magnitude (see Fig. 7 in Breton et al., 2012). Particle size distributions (PSDs) were determined by calculating the total volume of mineral dust contained within each size bin, assuming spherical dimensions, and then taking the derivative of the particle volume with respect to the derivative of the natural logarithm of the particle diameter for each bin $\left(\mathrm{d} V / \mathrm{d} \ln D\right.$ in $\left.\mu \mathrm{m}^{3} \mathrm{~mL}^{-1}\right)$. We use the mode particle diameter $\mu$ as a descriptive statistic for the center of the volume size distribution, following Ruth et al. (2003).
We applied the WDC06A-7 timescale, which is based on annual layer counting of chemical signals in the ice core. The timescale has an estimated age uncertainty of \pm 1 year for the depth range of 0-577 m, analyzed here (WAIS Divide Project Members, 2013). Annually resolved accumulation rates were calculated for the WAIS Divide core by using the depth-age relationship and applying a one-dimensional ice-flow model, as described by WAIS Divide Project Members (2013). To calculate dust flux, we applied these accumulation rates assuming 0.5 basal sliding fraction; different basal sliding fractions do not make a significant difference in the calculated accumulation rates during the Holocene (WAIS Divide Project Members, 2013).

\subsection{Automatic weather station data}

We obtained automatic weather station (AWS) data from the Antarctic Meteorological Research Center and Automatic Weather Stations Project server at the Space Science and Engineering Center, University of Wisconsin (Lazzara et al., 2012). We used wind speed and direction data, which were collected nominally every 10 minutes, although there were numerous instrument failures that caused gaps in data. Data were subjected to basic quality control prior to being archived; we removed data with zero values for both wind speed and direction, as these occurred over long spans of time, intermingled with data gaps, and appeared to be errors. Measurements span 2009-2012 for the WAIS Divide Field Camp AWS, named Kominko-Slade. For the months with archived data, we estimated the percentage of actual data measurements vs. data gaps for each season: DJF $90 \%$, MAM $82 \%$, JJA $37 \%$, and SON $47 \%$. As might be expected, the AWS functioned best in summer (DJF) and worst in winter (JJA). Even with the low data-recording rates during winter and spring, we believe these data provide a useful picture of general wind conditions at the WAIS Divide site that can be compared with reanalysis surface wind data.

\subsection{Reanalysis data}

We obtained ERA-Interim full-resolution, 6-hour daily field reanalysis data ( $76 \mathrm{~km}$ resolution) from the European Centre for Medium-Range Weather Forecasts research data server (Dee et al., 2011). From the $10 \mathrm{~m} U$ (zonal) and $V$ (meridional) wind components, we calculated wind speed ( $\left.W_{\mathrm{spd}}\right)$ and direction $\left(W_{\mathrm{dir}}\right)$ using the following equations (from www.eol.ucar.edu), which allowed us to compare reanalysis data directly to the AWS surface wind data.

$$
\begin{aligned}
& W_{\text {spd }}=\sqrt{U^{2}+V^{2}} \\
& W_{\text {dir }}=\tan ^{-1}(-U,-V) \times 180 / \pi
\end{aligned}
$$

Because the AWS data from WAIS Divide only span 20092012, we used this time period for comparison with the reanalysis $10 \mathrm{~m}$ wind speed and direction data. We used seasonal and annual mean 700 and $850 \mathrm{hPa} U$ and $V$ wind speed 


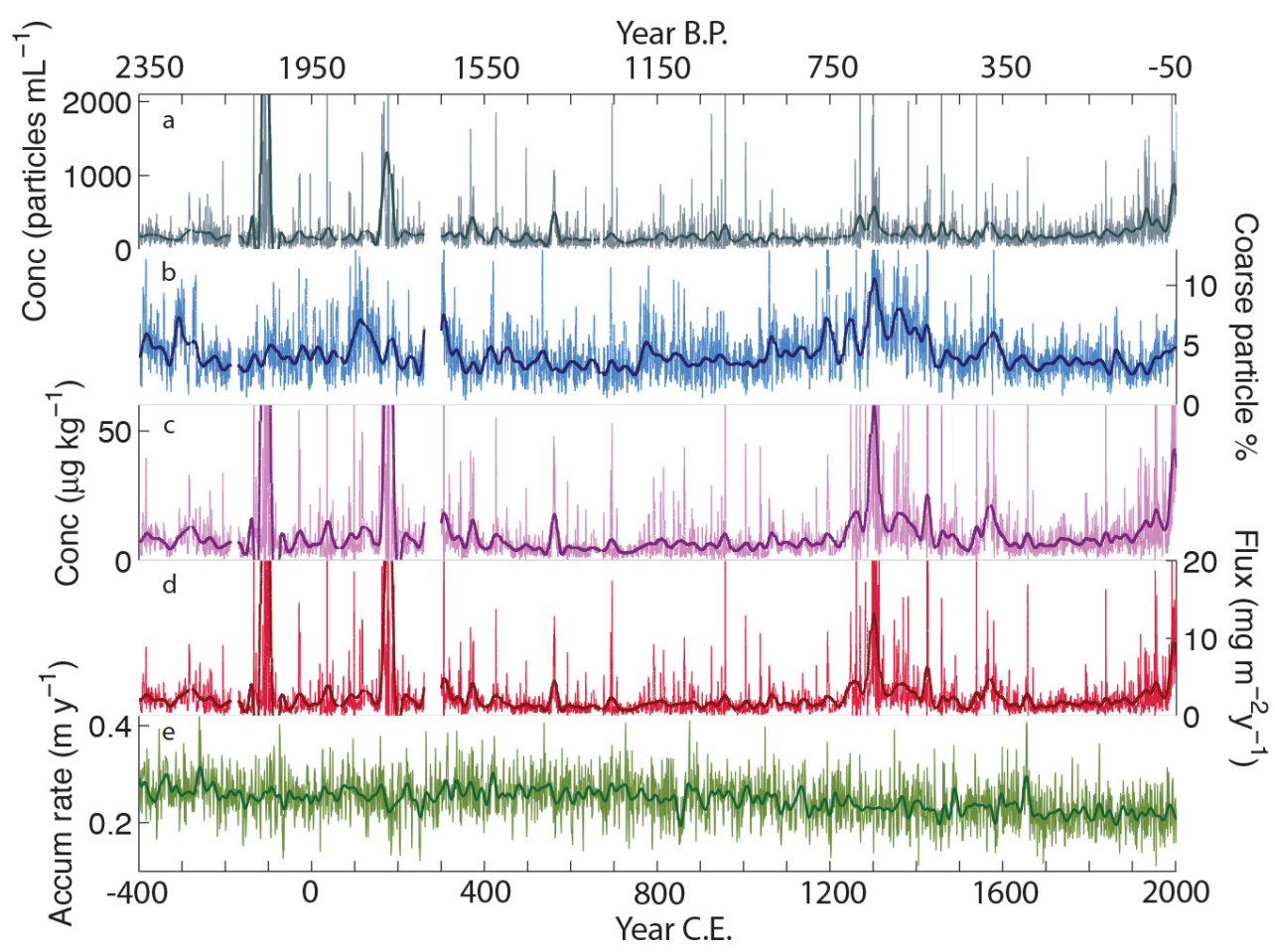

Figure 2. Dust time-series plots: (a) dust number concentration; (b) coarse particle percentage $\left(\mathrm{CPP}\right.$, defined as number of particles $\mathrm{mL}^{-1}$ [4.5-15]/[1-15] $\mu \mathrm{m}$ diameter $\times 100$ ); (c) dust mass concentration; (d) dust flux; and (e) accumulation rate in meters of water equivalent (from WAIS Divide Project Members, 2013). Thin lines show 1-year filtered data and thick lines show 21-year filtered data, except for (e), for which the raw data are annual (thin line); in this case the thick line shows the 21-year filtered record.

data to evaluate relationships between larger-scale circulation and our dust record. Spatial correlation maps show Pearson's linear correlations between zonal or meridional wind speed at each reanalysis grid point and the WAIS Divide dust size record for the period of overlap, 1979-2002.

\section{Results}

\subsection{Dust concentration, flux, and size distribution}

Dust flux varied between $\sim 2$ and $25 \mathrm{mg} \mathrm{m}^{-2}$ year $^{-1}$ for most of the past 2400 years, remaining generally around $3-5 \mathrm{mg} \mathrm{m}^{-2}$ year $^{-1}$. Dust mass concentration was typically $\sim 10-15 \mu \mathrm{g} \mathrm{kg}^{-1}$. The two records exhibit very similar patterns, suggesting that changes in mass concentration drive observed changes in flux (Fig. 2c-d). In other words, because the snow accumulation rate at WAIS Divide was relatively constant during the late Holocene, it appears to have had little to no influence on the dust concentration or flux (Figs. 2e, 3). Considering the lack of relationship seen between dust concentration and accumulation rate (linear regression slope $=2.5 ; r=0.01$; Fig. 3), we infer that a combination of dry and wet deposition occurs at this site. In contrast, if we saw a negative relationship between accumulation rate and dust concentration, we would infer a primarily dry dust deposition mechanism, while if flux scaled with accumulation, we would infer that wet deposition dominates (Kreutz et al., 2000a). Because the dust mass concentration and flux records are consistent, and because published dust flux values can be compared readily among sites with different snow accumulation rates (e.g., Wolff et al., 2006), we use dust flux as a measure of dust deposition for comparison with other records.

There are four intervals during which dust flux increases dramatically from background levels of $\sim 4 \mathrm{mg} \mathrm{m}^{-2}$ year $^{-1}$ to peaks near 10-25 mg m${ }^{-2}$ year $^{-1}$ : 122-90 BCE, $\sim 156$ 195 CE, 1230-1440 CE, and 1850-2002 CE (Fig. 2d). Because dust flux can be driven independently by changes in the number of particles deposited (i.e., dust particle number concentration, Fig. 2a) or by changes in the size distribution of those particles, we compare these three parameters. We use the coarse particle percentage (CPP; defined as number of particles $\mathrm{mL}^{-1}[4.5-15] /[1-15] \mu \mathrm{m}$ diameter $\times 100$ ) as a measure of the size distribution. From Fig. 2 we can see that the first two events are clearly visible in the number concentration data (Fig. 2a), but not present in the CPP record (Fig. 2b). In contrast, the major event around $\sim 1230$ $1440 \mathrm{CE}$ is present in all three parameters, but the structure and timing of changes is slightly different among them. The $\mathrm{CPP}$ begins to increase around the year $1050 \mathrm{CE}$, and ramps up slowly to a maximum of $9.9 \pm 2.7 \%$ at $\sim 1300 \mathrm{CE}$. It 


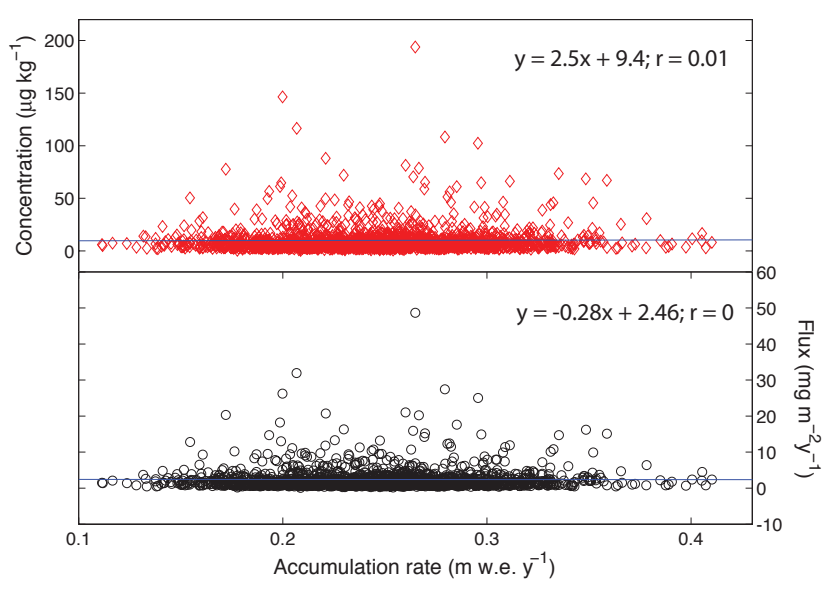

Figure 3. Dust concentration and flux plotted vs. accumulation rate; linear regressions are given.

remains elevated until a rapid drop to $3.7 \pm 1.1 \%$ around $\sim 1430 \mathrm{CE}$, followed by a second, smaller peak $(5.1 \pm 2.2 \%)$ spanning the period $\sim 1510-1610 \mathrm{CE}$. During the period from 1610 to $1960 \mathrm{CE}$, the CPP remains relatively low, at $3.5 \pm 1.1 \%$. In comparison, the dust number concentration shows a bimodal peak, with a maximum of $900 \pm 590$ particles $\mathrm{mL}^{-1}$ reached at $\sim 1300 \mathrm{CE}$, followed by a series of smaller peaks leading up to an increase beginning around $\sim 1820$ CE. The fourth interval with elevated dust flux, from $\sim 1850 \mathrm{CE}$ to the present, is characterized by a large increase in the dust number concentration (from $220 \pm 120$ particles $\mathrm{mL}^{-1}$ during the decade $1850-1860$ to $860 \pm 370$ particles $\mathrm{mL}^{-1}$ during the decade 1990-2002), but relatively little change in the CPP until much later, $\sim 1950 \mathrm{CE}$. The CPP averages $4.8 \pm 0.9 \%$ during the last decade of the record (1990-2002), and appears to be following an increasing trend (Fig. 7d).

In summary, we observe three patterns of behavior among the dust number concentration, the dust flux, and the CPP: (1) synchronous increases in the dust number concentration and flux records during the period $\sim 122-90 \mathrm{BCE}$ and $\sim 156-195$ CE with negligible change in the CPP; (2) a simultaneous peak in all three parameters at $\sim 1300 \mathrm{CE}$ but with different structures between the records; and (3) roughly synchronous increases in concentration and flux beginning in the mid-1800s and peaking at the present, with a later and smaller-amplitude change in the CPP during recent decades.

Although we primarily use the CPP as a measure of changes in PSD, the volume size distribution $\mathrm{d} V / \mathrm{d} \ln D$ provides additional information about dust source and transport. We can use both the shape of the distribution (Kok, 2011a, b) and its relative mode (Bory et al., 2010; Delmonte et al., 2010) to infer proximity to dust source, and can use changes in mode size to infer variability in transport strength (Delmonte et al., 2005; Ding et al., 2002; Ruth et al., 2003). We find that the background dust (i.e., non-volcanic) PSD

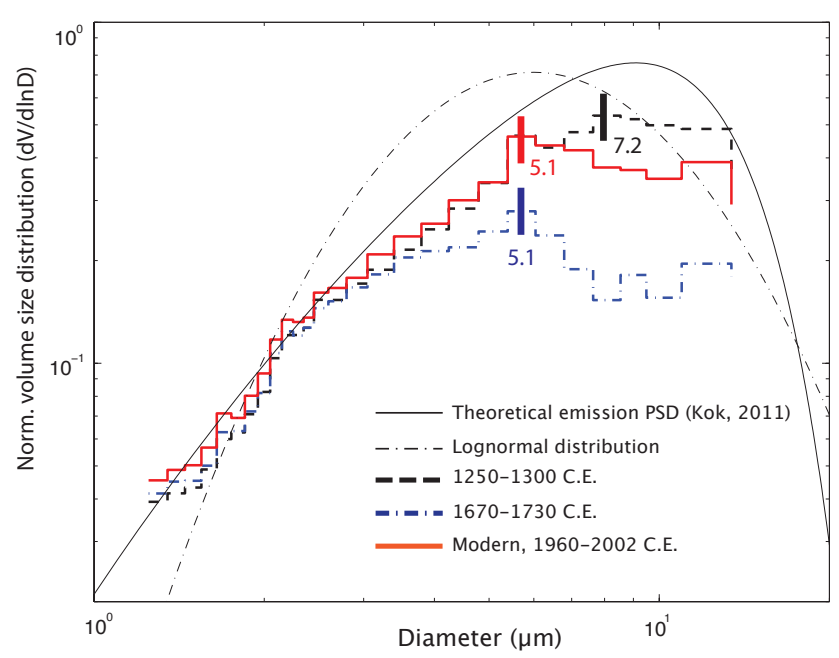

Figure 4. Normalized volume size distribution, $\mathrm{d} V / \mathrm{d} \ln D$, for three representative time periods along with theoretical dust emission particle size distribution (PSD) formulated by Kok (2011b) and a representative lognormal distribution. Vertical colored bars indicate the mode (most commonly occurring value) of each observed distribution. The lognormal distribution is parameterized as described by Delmonte et al. (2002), with mode diameter $=6 \mu \mathrm{m}$ and geometric standard deviation $=1.75$.

has a mode diameter that varies between $\sim 5-8 \mu \mathrm{m}$ (Fig. 4). We selected three representative time intervals to include in Fig. 4, to demonstrate how the volume size distribution relates to the CPP: 1250-1300 CE (high CPP, mode $7.2 \mu \mathrm{m}$ ), 1670-1730 CE (low CPP, mode 5.1 $\mu \mathrm{m}$ ), and 1960-2002 CE (high CPP, mode $5.1 \mu \mathrm{m}$ but with greater contribution from coarse particles compared to the earlier interval). For comparison, Fig. 4 also shows a lognormal distribution centered on $6 \mu \mathrm{m}$ and the theoretical dust volume size distribution at emission, which is based on evidence that dust emission is a scale-invariant process (Kok, 2011b). In other words, the emitted dust PSD depends on the source soil PSD, and not on the wind speed at the emission site (Kok, 2011a, b). The shape of the WAIS Divide volume size distribution approaches that of the theoretical emission size distribution, suggesting that while the dust must be transported some distance from its source, it is not traveling as far as the Patagonian dust reaching East Antarctic ice core sites, which has a lognormal or Weibull distribution with a mode diameter close to $2 \mu \mathrm{m}$ (Delmonte et al., 2002). It appears that while we captured the center (mode) of the distribution, we did not observe the entire size distribution of particles deposited at WAIS Divide because of our analytical limit of $15 \mu \mathrm{m}$ diameter. Future work in central West Antarctica should strive to analyze particles in a larger size range (e.g., up to $30 \mu \mathrm{m}$ diameter) in order to determine the nature of the size distribution, and whether it is unimodal or polymodal. 

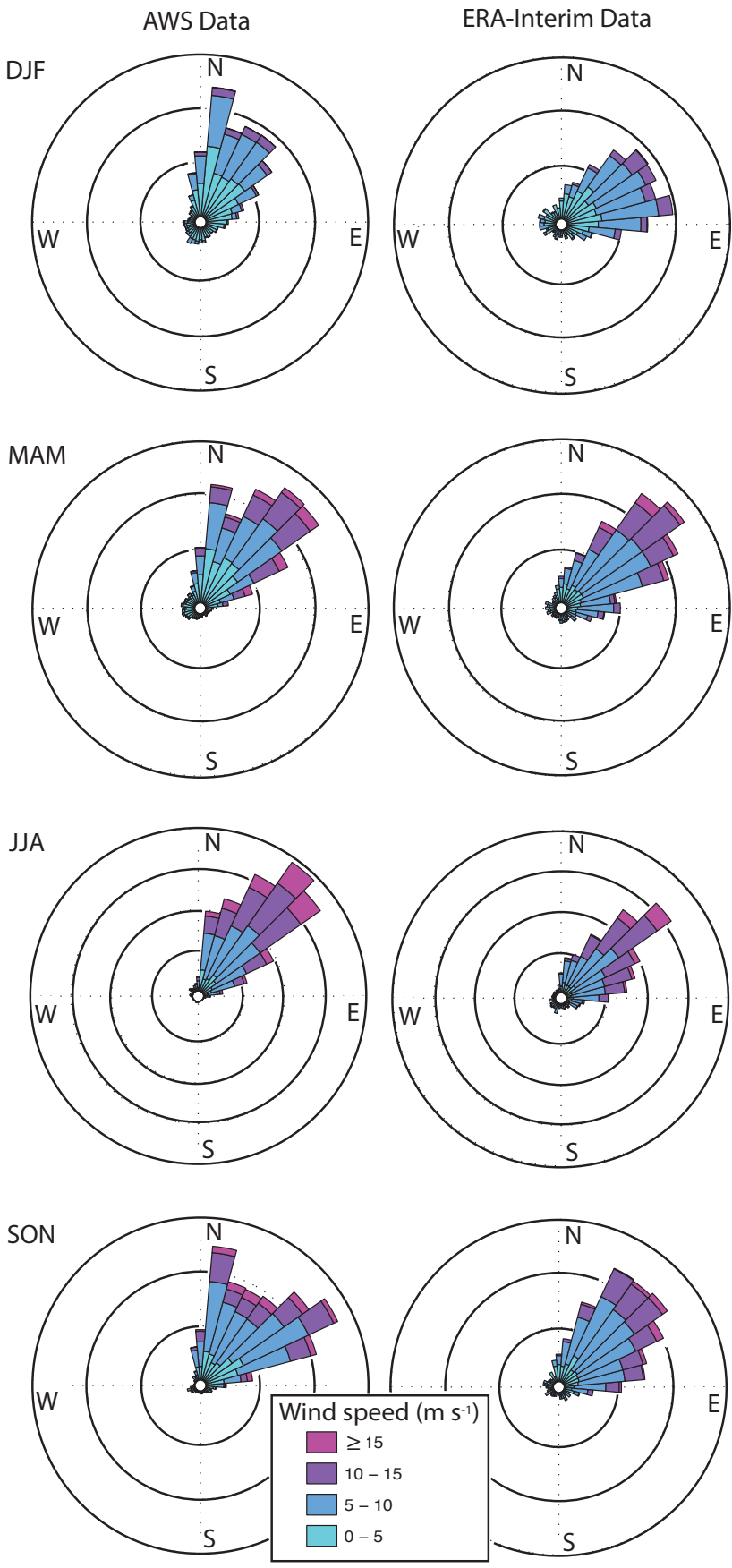

Figure 5. Automatic weather station (left) and ERA-Interim (right) surface wind speed and direction data by season from the WAIS Divide site. Wind rose plots show the frequency with which winds come from a given direction. Each dotted circle represents $5 \%$ of observations. True cardinal directions are indicated.

\subsection{Regional wind characteristics}

Both AWS data and ERA-Interim reanalysis data from the WAIS Divide site illustrate seasonal patterns in local wind speed and direction (Fig. 5). We observe a consistent pattern of onshore winds, with the predominant surface wind direction being approximately from the northeast. The two data sets agree well, although the ERA-Interim summer (DJF) winds show a stronger easterly component than do the observational data. Winds of all recorded speeds come from this dominant direction; in other words, there is no pattern of stronger winds coming from one direction, and weaker winds coming from another. However, we do observe seasonal patterns in wind strength: winter (JJA) wind data have the greatest percentage of recorded wind speeds over $15 \mathrm{~m} \mathrm{~s}^{-1}$ and summer wind data have the lowest. The patterns in the reanalysis data are verified by the instrumental record. Because the data recording frequency is every $10 \mathrm{~min}$ for the AWS data and every $6 \mathrm{~h}$ for the ERA-Interim data, we suspect that high wind speed events will be recorded more frequently in the observational record, which appears to be the case.

\subsection{Relationship between winds and coarse particle percentage}

We see a significant positive correlation $(r=0.3-0.5$, $p<0.1)$ between the annual mean mid-latitude westerly zonal $(U)$ wind speed and the annual mean CPP at both $700 \mathrm{hPa}$ (Fig. 6a) and $850 \mathrm{hPa}$ (not shown). Winds at $700 \mathrm{hPa}$ correspond roughly to $2600 \mathrm{~m}$ a.s.l., higher than the ice sheet surface for most of West Antarctica (Nicolas and Bromwich, 2011), and are therefore most representative of the circulation patterns bringing dust to the WAIS Divide site. Looking at the correlations between annual mean CPP and seasonal mean zonal wind speed for each season, we see some variability in the longitudinal regions of highest correlation (Fig. 6c-f). During summer (DJF) and fall (MAM), the CPP is significantly correlated $(r=0.3-0.5, p<0.1)$ with zonal winds in much of the SWW belt (Fig. 6c-d). In contrast, the winter (JJA) and spring (SON) correlation maps show greater zonal "patchiness" (Fig. 6e-f). In winter, the area of strongest correlation $(r=0.4-0.5, p<0.1)$ spans the region from $\sim 100^{\circ} \mathrm{E}$ to $\sim 150^{\circ} \mathrm{W}$, to the west of the AmundsenBellingshausen Sea region. In spring, the region of strongest correlation $(r=0.3-0.5, p<0.1)$ spans the area offshore from Victoria Land to the Amundsen Sea $\left(\sim 180^{\circ} \mathrm{W}\right.$ to $\sim 120^{\circ} \mathrm{W}$ ). These differences may relate to zonal differences in the relative strength of winds in different seasons, likely driven by changes in the position of the Amundsen Sea Low pressure center (Kreutz et al., 1997, 2000b), and also likely reflect the fact that the circumpolar winds are most annular during summer and fall (Jones et al., 2009). Another possibility is that the stronger summer correlation reflects a real difference in SWW position, as the wind belt is located farther to the south in summer (Lamy et al., 2010). 
a) Zonal (Annual)

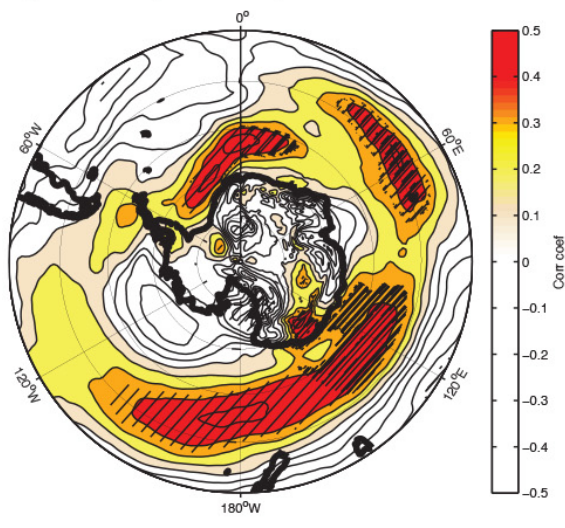

c) Zonal (DJF)

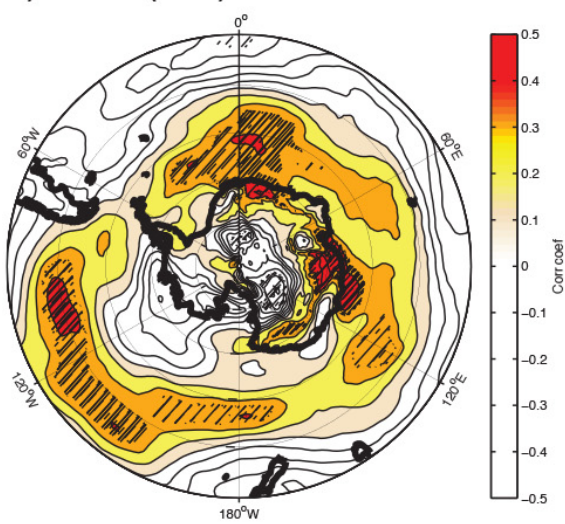

e) Zonal (JJA)

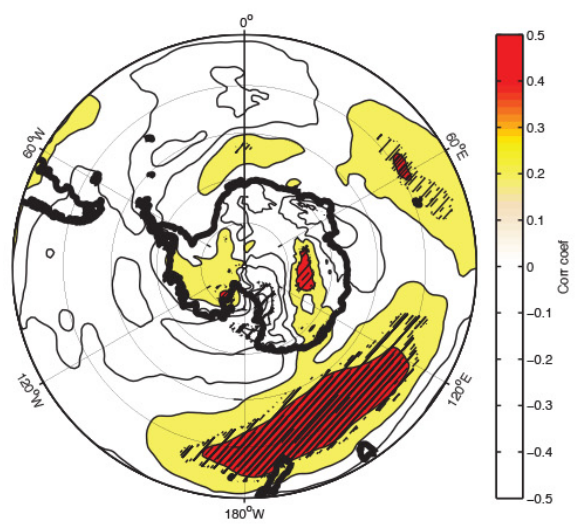

b) Meridional (SON)

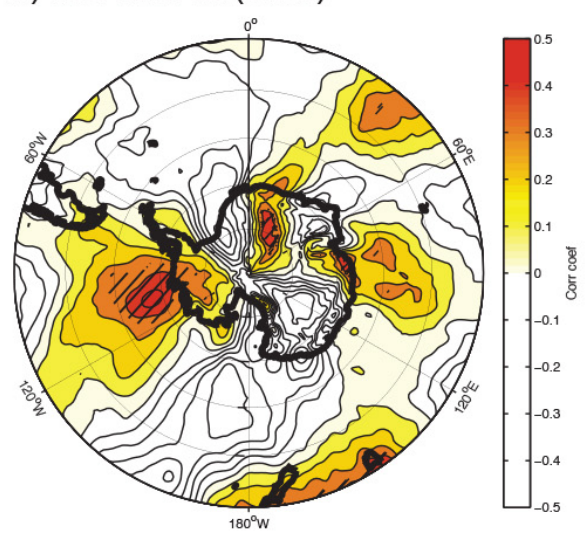

d) Zonal (MAM)

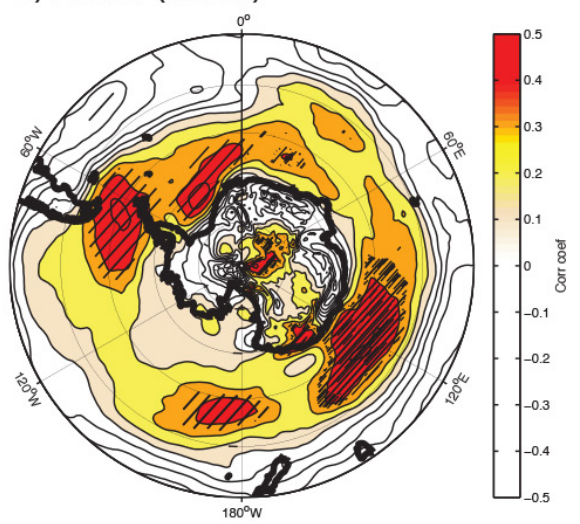

f) Zonal (SON)

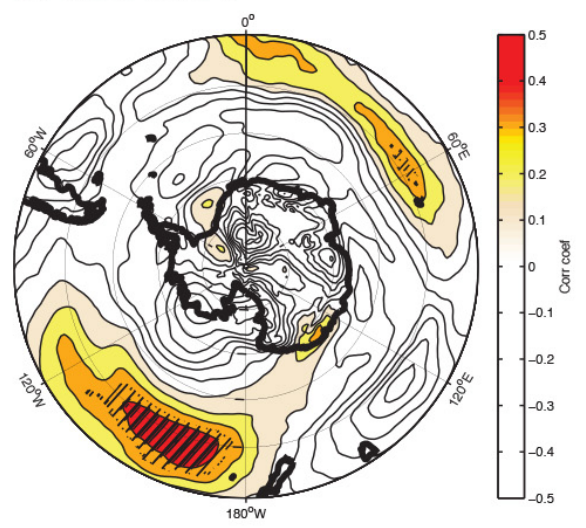

Figure 6. Spatial correlation maps showing Pearson's linear correlation coefficient (colors) and regions of $90 \%$ significance (hatching) for correlation between WAIS Divide coarse particle percentage (CPP) and $700 \mathrm{hPa}$ wind speed, 1979-2002: (a) annual mean zonal wind, (b) spring (SON) meridional wind, (c) summer (DJF) zonal wind, (d) fall (MAM) zonal wind, (e) winter (JJA) zonal wind, and (f) spring (SON) zonal wind. For clarity, we have colored only regions of positive correlation.

Considering that the mid-latitude westerlies do not directly impact the WAIS Divide site at $79^{\circ} \mathrm{S}$, and that the circulation is dominantly onshore (Figs. 1b, 5), we assessed the relationship between meridional $(\mathrm{N}-\mathrm{S})$ winds in the Amundsen Sea region and the WAIS Divide CPP. We find significant positive correlations $(r=0.3-0.5, p<0.1)$ between these pa- rameters, which are strongest during spring (SON, plotted in Fig. 6b) and summer (DJF), coinciding with the timing of peak dust deposition at WAIS Divide. 


\section{Discussion}

\subsection{Grain size distribution and likely dust source(s) for West Antarctica}

Our measured PSD, with a mode size around 5-8 $\mu \mathrm{m}$, is comparable to those measured at other non-EAIS plateau sites, including Talos Dome (2315 m a.s.l.) and Berkner Island (899 m a.s.1.). Bory et al. (2010) found a substantial contribution of dust mass from $>5 \mu \mathrm{m}$ diameter particles in surface snow at Berkner Island (a mode size was not reported). Using $\mathrm{Sr}$ and $\mathrm{Nd}$ isotopic data in conjunction with grain size measurements, they inferred the presence of an Antarctic dust source, in addition to a Patagonian dust source, with different sources predominating in different seasons (Bory et al., 2010). Similarly, the Holocene section of the Talos Dome ice core dust record is dominated by particles in the $5-10 \mu \mathrm{m}$ diameter range, suggesting proximal dust sources (Albani et al., 2012). Delmonte et al. (2010) investigated dust provenance using $\mathrm{Sr}$ and $\mathrm{Nd}$ isotopes, and found that the Holocene dust signature matches nearby sources in the Transantarctic Mountains. In contrast, during glacial times the Talos Dome dust PSD approximated a lognormal distribution with a mode size around $2 \mu \mathrm{m}$ diameter (Albani et al., 2012) and the isotopic signature reflected dust input primarily from Patagonia (Delmonte et al., 2010), suggesting that local dust sources may have been covered by permanent snow or ice at this time (Albani et al., 2012). Holocene dust sizes measured at these sites are all relatively coarse compared to the $\sim 2 \mu$ m modal values measured in the Vostok and EPICA Dome $\mathrm{C}$ ice cores from central East Antarctica (e.g., Delmonte et al., 2002). According to a range of geochemical and isotopic evidence, the East Antarctic plateau receives dust primarily from Patagonia, located approximately $6000-7000 \mathrm{~km}$ away, although other sources, such as Australia, may contribute during interglacial periods (Basile et al., 1997; Delmonte et al., 2004, 2008; Revel-Rolland et al., 2006; Marino et al., 2008, 2009). Given the particle size similarities between WAIS Divide and other non-plateau sites, it seems plausible that much of Antarctica has a dust size signature that differs from that of central East Antarctica. Coarser PSDs likely indicate shorter dust transport distances and may imply a predominance of local (Antarctic) sources.

Observed differences in grain size distributions between East Antarctic plateau sites ( 3200-3500 ma.s.l.) and lower-elevation sites such as Berkner Island, Talos Dome, and WAIS Divide may also indicate differences in the transport altitude of atmospheric dust, as suggested by Bory et al. (2010). While dust from the major Southern Hemisphere dust sources, Patagonia and Australia, is transported at altitudes of $>4000 \mathrm{~m}$ ( $\mathrm{Li}$ et al., 2008; Krinner et al., 2010), it is possible that dust from Antarctic sources, which are poorly characterized, may travel too low in the troposphere to reach the East Antarctic plateau. A possible analog occurs in Asia, where Wu et al. (2009) found a negative correlation between glacier elevation and particle size in ice core samples from the Tibetan Plateau, consistent with the observed Antarctic pattern. Particles in cores from the Muztagata glacier at 6250 and $6350 \mathrm{~m}$ a.s.l. had mean mode sizes of 5.87 and $5.74 \mu \mathrm{m}$, respectively, coarser than the mean mode size of $4.99 \mu \mathrm{m}$ measured at $7010 \mathrm{~m}$ a.s.l.; PSDs at the higher elevation site were also less variable (Wu et al., 2009). Thus, we interpret the observed decrease in grain size with elevation to reflect decreasing influence of local dust emissions.

In addition to particle size information, the general shape of a dust PSD curve can be used to infer transport distance (Kok, 2011a). The WAIS Divide PSD differs from the PSDs of dust from Greenland (Steffensen, 1997; Ruth et al., 2003) and central East Antarctica (Delmonte et al., 2002), which are lognormal. Instead, it falls somewhere between a lognormal distribution and a distribution of dust particles near their emission source (Fig. 4; Kok, 2011a). Considering both the coarser mode size compared to central EAIS dust and the shape of the distribution, we infer a relatively shorter dust transport distance in central WAIS compared to the EAIS plateau.

Given the dominant wind direction from the AmundsenBellingshausen Sea region to the WAIS Divide site (Fig. 5), we believe that potential nearby dust sources would have to be located in coastal Marie Byrd Land. We suggest that the consistency of wind direction from this coastal region during all seasons makes dust contributions from sites in the Transantarctic Mountains, Ellsworth Mountains, or other nunataks located to the south and west unlikely. Modeling studies suggest either a predominance of Australian dust or a roughly 50/50 mixture of South American and Australiansourced dust to the WAIS at present (Li et al., 2008; Albani et al., 2011). However, to our knowledge, no studies have yet evaluated the possible role of dust from other sources, such as New Zealand or the particularly dusty Dry Valleys west of McMurdo Sound, Antarctica. Reanalysis wind data show that the McMurdo Sound region is dominated by southerly flow (Fig. 1b), suggesting that dust from the Dry Valleys could enter the southern margin of the SWW belt and be transported to WAIS Divide. While distal dust sources such as Australia and New Zealand may indeed influence West Antarctica, it is likely that far-traveled dust is too fine to have had much effect on the PSD at WAIS Divide - at least during the late Holocene. Additional work will be needed to assess the extent, emissions activity, and geochemical signature of Antarctic potential dust source areas, as well as the geochemical signature of dust deposited at WAIS Divide.

\subsection{Flux comparison to other sites}

The WAIS Divide late Holocene background (i.e., nonvolcanogenic) dust flux of $\sim 4 \mathrm{mg} \mathrm{m}^{-2}$ year $^{-1}$ appears to be intermediate between coastal sites in the Weddell Sea region and sites located on the East Antarctic plateau. A factor of $\sim 3$ higher dust flux $\left(12 \mathrm{mg} \mathrm{m}^{-2}\right.$ year $^{-1}$ ) was reported 
for the mid-to-late 19th century at James Ross Island, near the tip of the Antarctic Peninsula and close to Patagonian dust sources (McConnell et al., 2007). Similarly, although flux values have not been reported for the Berkner Island ice cores, the average dust concentration of $1220 \pm 1110$ particles $\mathrm{mL}^{-1}$ is 5 times that observed at WAIS Divide (230 \pm 350 particles $\mathrm{mL}^{-1}$ ) for the same time period (1080$1994 \mathrm{CE}$ ), while the accumulation rate is $\sim 60 \%$ lower (average: $130 \mathrm{~kg} \mathrm{~m}^{-2}$ year $^{-1}$ vs. $207 \mathrm{~kg} \mathrm{~m}^{-2}$ year $^{-1}$ at WAIS Divide; Ruth et al., 2004; Banta et al., 2008). Given the predominance of particles in the $5-10 \mu \mathrm{m}$ diameter range at Berkner, we infer that the dust mass flux is likely greater than at WAIS Divide. In addition, Bory et al. (2010) report that the dust flux measured at Berkner Island is similar to that measured at Kohnen Station, Dronning Maud Land (2892 $\mathrm{m}$ a.s.1.) for small ( $<3 \mu \mathrm{m}$ diameter) particles, but is up to 3.5 times higher for particles in the $3-9 \mu \mathrm{m}$ diameter range. This observation is consistent with the idea that coastal and lower-elevation sites display a coarser dust size distribution than sites at higher elevations, perhaps due to local dust source activity (Bertler et al., 2005). On the eastern margin of the EAIS, the late Holocene dust flux at Talos Dome was $\sim 1 \mathrm{mg} \mathrm{m}^{-2}$ year $^{-1}$ for particles of $1-10 \mu \mathrm{m}$ diameter (Albani et al., 2012). In contrast to these coastal and lower-elevation sites, the interglacial dust flux reported from the EPICA Dome C ice core, $0.2-0.6 \mathrm{mg} \mathrm{m}^{-2}$ year $^{-1}$, is about an order of magnitude lower (Lambert et al., 2012).

Overall, these observations imply a meridional gradient in dust flux, as suggested by Edwards et al. (2006), based on atmospheric iron flux measurements from the Law Dome and EPICA Dome $\mathrm{C}$ ice cores. Because dust volume (and therefore mass) scales with the cube of the particle radius, we suggest that differences in particle size (rather than number) drive this flux gradient. This argument lends additional support to the idea that non-glaciated areas along the margins of the Antarctic ice sheets contribute a substantial amount of dust to the atmospheric dust burden over Antarctica, at least below $\sim 3000 \mathrm{~m}$, and implies that this locally sourced dust may also play a role in fertilizing the Southern Ocean.

A full analysis of the dust concentration and flux time series is beyond the scope of this paper and will be addressed in future work. We focus now on interpreting the observed changes in dust size distribution.

\subsection{Dust size distribution changes}

There are several possible interpretations for observed coarsening of the dust PSD: (1) a change from a more distal to a more proximal dust source; (2) a shift toward coarser particles at the emission site; and (3) increased transport efficiency, either through a change in circulation patterns or through increased wind strength. The first possible interpretation would require the activation of a local (i.e., Antarctic) dust source (or sources) during the time interval of observed increased CPP ( 1050-1430 CE), followed by an abrupt de- activation. In this case, we would expect mixing of dust from two source regions, one distal, such as Australia, and the other proximal, with the latter contributing varying fractions of the total dust through time. Considering that the availability of sediment from such a local source would most likely be controlled by snow accumulation, we can use West Antarctic snow accumulation rates to argue against this interpretation. In addition to the annual accumulation rates from the WAIS Divide deep ice core (Fig. 2e; WAIS Divide Project Members, 2013), Banta et al. (2008) calculated accumulation rates for three ice cores from the WAIS Divide region: ITASE 001, WDC05A, and WDC05Q. While these records do not extend earlier than the year $1521 \mathrm{CE}$, they provide an estimate of spatial variability in snow accumulation rate and can be used to compare to the past few centuries' dust PSD. Accumulation rates at all four sites remained relatively constant during the late Holocene, suggesting that changes in regional precipitation were unlikely to have driven the observed shifts in PSD. Further, if local sources were responding to changes in regional precipitation, we would expect to see an inverse relationship between dust flux and accumulation rate; however, we see no relationship (linear regression slope $=-0.28$; $r=0$; Fig. 3). Moreover, the relatively constant snow accumulation rate and lack of relationship between accumulation and dust mass concentration argue against significant changes in atmospheric moisture content, which could affect rates of particle aggregation during transport and therefore our dust size distribution record.

The second possible interpretation, of a shift in the dust PSD at the emission site, seems unlikely given typically slow changes in soil grain size, and recent work showing that the dust size distribution at emission is independent of wind speed (Kok, 2011a). Contrary to conventional wisdom, Kok (2011a) showed through a compilation of field measurements that dust PSD does not vary with surface wind stress. Assuming a constant soil/sediment PSD at the source, which determines the dust size at emission (Kok, 2011b), this suggests that observed increases in mean particle size in terrestrial dust archives reflect either a more proximal source, or stronger transporting winds (Kok, 2011a).

Based on these arguments and on the significant positive correlations we observe between the CPP and zonal wind speed, we interpret the observed changes in dust PSD to represent wind strength variability. While the coarseness of the PSD in West Antarctica (in both Byrd and WAIS Divide ice cores) may indicate the presence of a local source, we do not find evidence for the turning off and on of such a possible source. Rather, we suggest that the sources themselves remained constant and that our observed PSD changes reflect changes in the winds transporting the dust. 


\subsection{Reconstructions of past atmospheric circulation in Antarctica}

Nicolas and Bromwich (2011) note that Marie Byrd Land is the only region in Antarctica where mean katabatic flow has a strong southward component, effectively resulting in parallel surface and $700 \mathrm{hPa}$ flow, as is evident in our comparison of $10 \mathrm{~m}$ and higher-altitude wind data (e.g., compare wind directions in Figs. 1b and 5). Because of the unusual relationship between surface and middle troposphere winds in this region, we suggest that central West Antarctica is a site well-suited to paleowind reconstruction. The significant correlations we find between mid-latitude zonal wind speed and the CPP support wind strength as the driving cause of the observed changes in dust particle size.

Our interpretation linking local wind speed to larger-scale circulation is consistent with recent analyses of zonal wind speed and cyclogenesis in the Amundsen-Bellingshausen Sea region. Lubin et al. (2008) found that during positive Southern Annular Mode (SAM) polarity, zonal wind speed intensifies and winter-spring cyclogenesis increases. We suspect that the frequency and intensity of cyclones in this region are key drivers of changes in dust PSD, and that when the SWW shift equatorward or weaken, the WAIS Divide site is less influenced by these cyclones. Thus, we can use our record in conjunction with others spanning the mid-to-high southern latitudes to develop a hypothesis for past westerly wind behavior.

Previous studies have linked westerly wind strength with WAIS dust deposition, using the crustal dust tracer nssCa. Yan et al. (2005) found significant positive correlations between the mid-latitude zonal winds and nssCa concentrations in the Siple Dome (coastal WAIS) and ITASE 00-1 (central WAIS) ice cores during recent decades. Dixon et al. (2012) expanded this work by using stacked nssCa concentrations from 10 ice cores to develop a proxy for "northerly air mass incursions" (NAMI) into central West Antarctica for the interval 1870-1998 CE. They observe an increasing trend in nssCa concentrations beginning around $1960 \mathrm{CE}$, close to the time we see the CPP at WAIS Divide begin to increase (Fig. 7b-c). Given a demonstrated relationship between nssCa and insoluble particles (Ruth et al., 2008; Lambert et al., 2012), the similarities between these records make sense. However, a microparticle record contains independent information on environmental/dust source changes and transport changes, whereas nssCa concentrations reflect the combined influence of particle size and number, effectively giving a combined signal of source and transport effects. Therefore, we suggest that the dust PSD provides a more robust tool for investigating the strength of the circum-Antarctic atmospheric circulation in the pre-instrumental era, as it is based on a physical relationship between wind strength and particle size.

Other high-resolution ice core records from Antarctica also have been used to infer past changes in atmospheric circulation. Sea-salt sodium (ssNa) concentrations in the Siple Dome ice core have been interpreted as a proxy for the Amundsen Sea Low (ASL), a persistent feature of the circum-Antarctic atmospheric circulation (Kreutz et al., 1997, 2000b; Maasch et al., 2005). The Law Dome (coastal EAIS) ice core ssNa record has been used to reconstruct variability in the SAM, based on a statistical relationship between early winter seasonal ssNa concentrations and mean sea-level pressure (Souney et al., 2002; Goodwin et al., 2004, 2013; Vance et al., 2013). In both cases, enhanced ssNa deposition has been interpreted as an indicator of increased meridional transport from the ocean to the ice core site. However, ssNa is also produced during the formation of frost flowers as sea ice freezes (Wagenbach et al., 1998; Rankin et al., 2000). Several studies have shown that $\mathrm{ssNa}$ is an effective proxy for sea ice extent, particularly at Antarctic coastal sites, suggesting that its variability is not driven solely by enhanced storminess (Rankin et al., 2002; Wolff et al., 2003, 2006). Because ssNa deposition may be influenced by multiple factors, we do not attempt to relate observed changes in the Siple and Law Dome ice core ssNa records to those we describe in the WAIS Divide microparticle record.

\subsection{Recent circum-Antarctic circulation changes}

Since the 1950s, the SAM has trended toward increasing positive polarity (i.e., increasingly low pressure over Antarctica), characterized by a strengthening polar vortex and intensification of the SWW (Thompson and Solomon, 2002; Marshall, 2003). The tropospheric trend is strongest in summer (DJF) and autumn (MAM), when the SAM is most annular (Jones et al., 2009). While recent work has shown that these changes have been driven primarily by stratospheric ozone loss (Thompson and Solomon, 2002; Arblaster and Meehl, 2006; Thompson et al., 2011; Lee and Feldstein, 2013), it is also clear that the SAM has varied significantly over the past 140 years, likely in response to natural forcings (Jones et al., 2009). Differences among SAM indices have been discussed elsewhere (Jones et al., 2009; Ho et al., 2012), so we shall not do so here but rather treat them in aggregate, as they show very similar patterns of variability. We use a summer (DJF) measure of the SAM (Fig. 7a), as this season is thought to be most robust (Jones et al., 2009), and because dust deposition in West Antarctica primarily occurs in the spring/summer.

Over the past $\sim 130$ years, the CPP record peaks at times that are consistent with positive SAM, but the two records do not covary (Fig. 7a, b). This likely reflects the fact that the WAIS Divide site is influenced almost exclusively by cyclonic systems and onshore winds in the AmundsenBellingshausen Sea region, whereas the SAM indices represent zonal and seasonal averages in sea-level pressure (SLP). Although cyclones in the Amundsen-Bellingshausen Sea region are linked to the SAM (Lubin et al., 2008), it is not a one-to-one relationship. The CPP record thus reflects the greater synoptic-scale variability in this region. Beginning in 


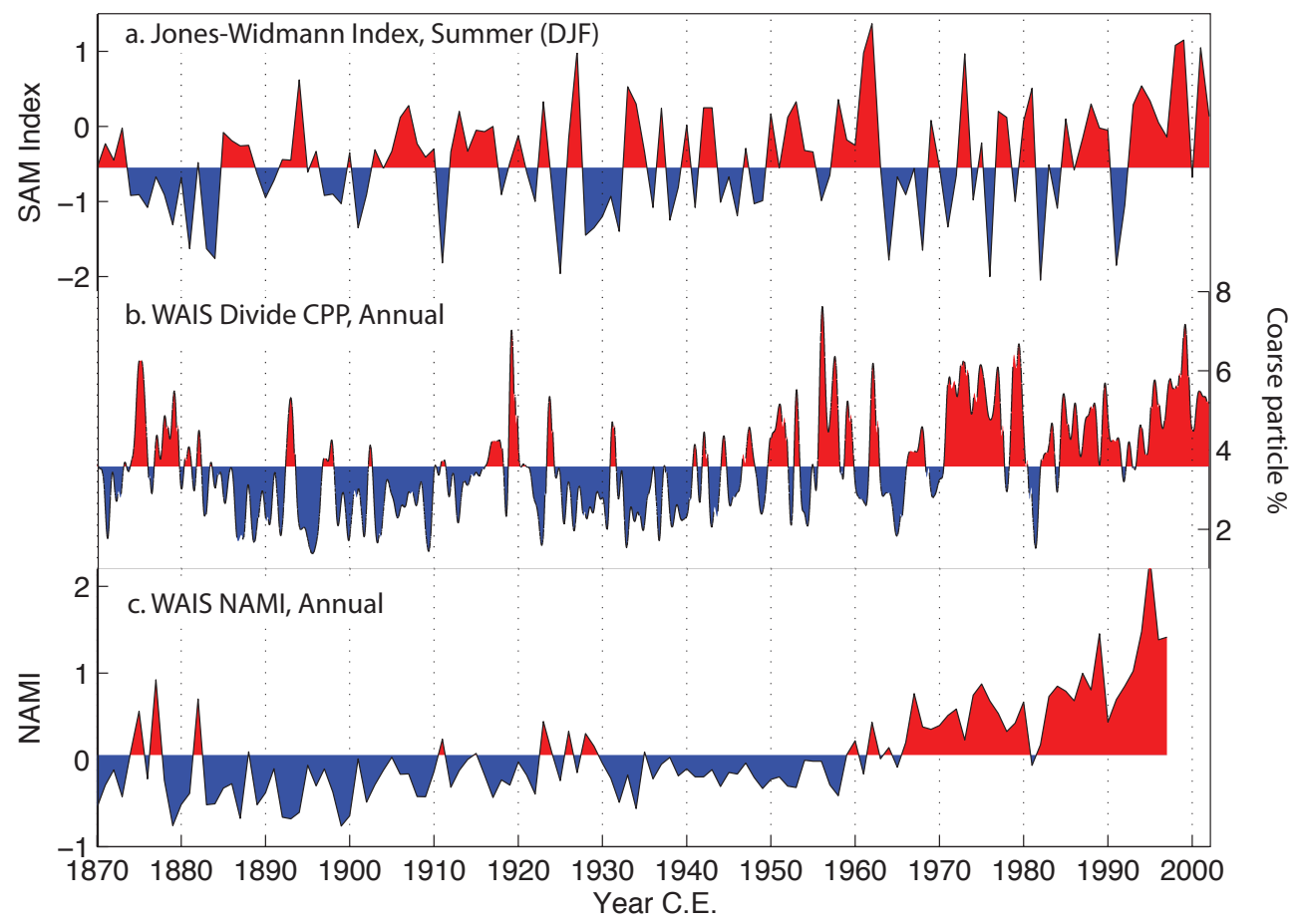

Figure 7. Comparison of Southern Annular Mode (SAM) index and West Antarctic circulation proxies for the period 1870-2002 CE: (a) Jones-Widmann Index (JWconcat), based on the first principal component of extratropical SLP, using both ERA-40 climate reanalysis data and station measurements (Jones et al., 2009). (c) WAIS Divide coarse particle percentage (this work). (e) Proxy for "northerly air mass incursions" (NAMI) into West Antarctica, based on stacked nssCa concentration data from 10 ice cores (Dixon et al., 2012). The red/blue delineation for each curve is the mean of that record over the time interval shown.

$\sim 1950$ CE, we see a step-like change toward higher-thanaverage CPP values, consistent with the observed trend in the SAM. Similar to the CPP record, the NAMI proxy shows a change toward higher-than-average values beginning in $1960 \mathrm{CE}$, indicating greater meridional transport of dust into West Antarctica (Fig. 7c; Dixon et al., 2012). Although neither the CPP nor the NAMI proxy covary with the SAM, it is evident that they both reflect changing atmospheric circulation conditions beginning around 1950-1960 CE.

\subsection{Southern Hemisphere records of westerly wind variability}

Given the demonstrated relationship between regional atmospheric circulation strength and the CPP record from WAIS Divide, we interpret the CPP record in terms of variability in the SWW. We infer stronger SWW and/or a more poleward position from $\sim 1050-1430 \mathrm{CE}$ (i.e., during the MCA), and weaker SWW and/or a more equatorward position from $\sim 1430-1950$ CE (i.e., during the LIA, with a minor strengthening or poleward shift from $\sim 1510-1610 \mathrm{CE}$ ). Prior to $\sim 1050 \mathrm{CE}$, our record indicates variability in the SWW, with short intervals of enhanced strength and/or a more southerly position at 84-160 CE, 255-345 CE (Fig. 8, gray bars). In addition, there appears to be a threshold effect, in that our CPP proxy seems to be sensitive primarily to stronger and/or more southerly shifted SWW. Thus, we do not see decreases in the CPP below the baseline range of $\sim 3-4 \%$ coarse particles at times when we infer weaker and/or equatorwardshifted SWW. We suggest that paleoclimate records from farther north can better be used to track northward shifts or expansions of the SWW belt. Although we cannot obtain information on SWW latitudinal position from one site alone, we can use our record in conjunction with climate reconstructions from the SH middle latitudes to develop a hypothesis for how the SWW belt has changed in latitudinal position through time.

The SWW are the primary driver of rainfall variability on the windward (western) side of the Chilean Andes (Fletcher and Moreno, 2012; Kilian and Lamy, 2012), allowing the use of a range of tools to infer past changes in rainfall, moisture balance and westerly wind variability. Kilian and Lamy (2012) offer an excellent review of paleoclimate reconstructions from southern Patagonia; we focus here on two records from the northern margin and the core of SWW influence, respectively.

The iron concentration record of marine core GeoB 3313$1\left(\sim 41^{\circ} \mathrm{S}\right)$, drilled on the Chilean continental slope, reflects the geologic source of sediment and in turn, the rainfall history of the region (Lamy et al., 2001). High rainfall brings material from the relatively iron-poor Coastal Range, while 


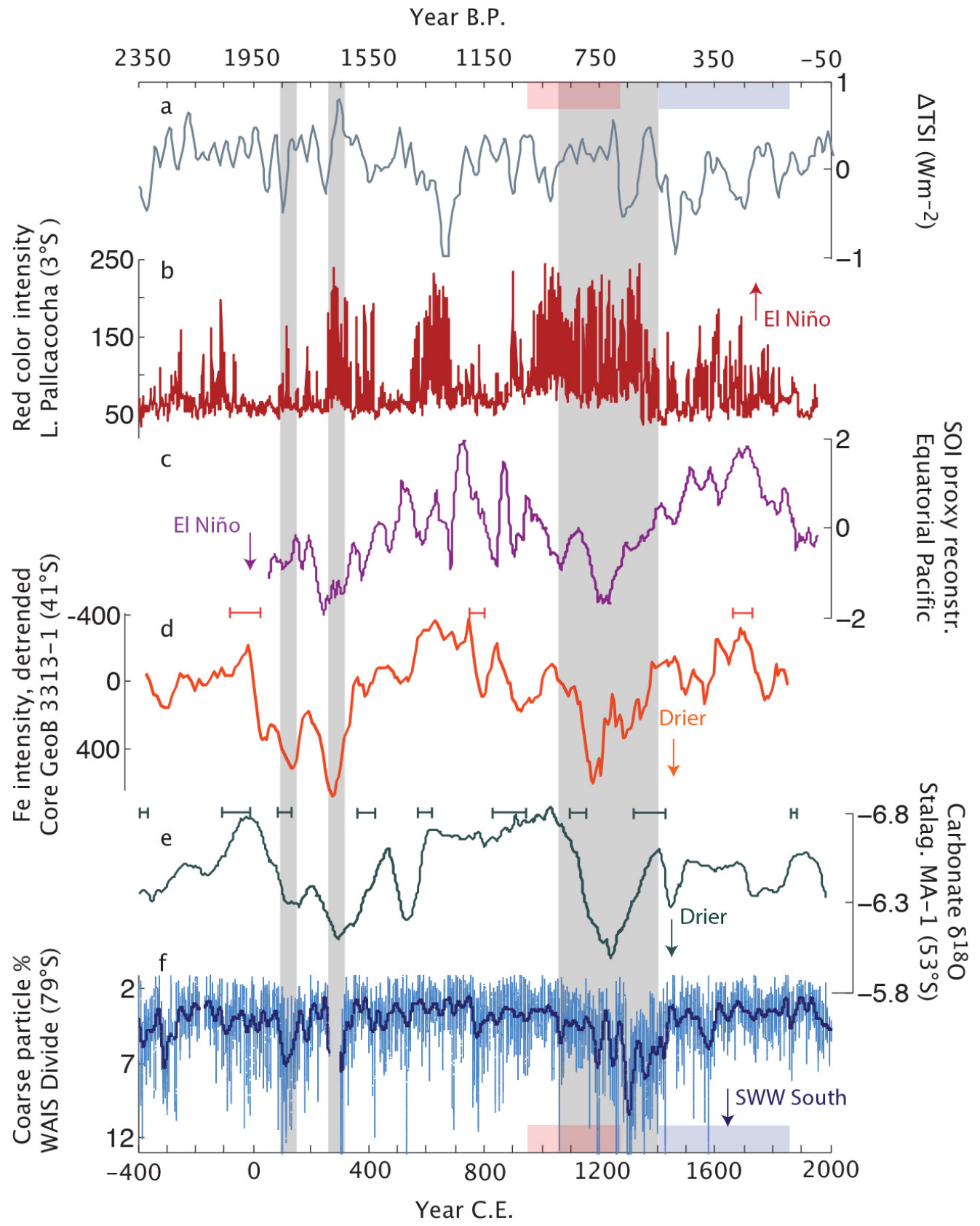

Figure 8. Paleoclimate reconstructions from the eastern Pacific region: (a) Change in total solar irradiance (TSI) based on variability of cosmogenic ${ }^{10} \mathrm{Be}$, the production of which is modulated by the strength of the open solar magnetic field (Steinhilber et al., 2009). (b) Red color intensity record of sediments from Laguna Pallcacocha, Ecuador; greater color intensity indicates more El Niño-driven high precipitation events (Moy et al., 2002). (c) Southern Oscillation Index (SOI) precipitation-based reconstruction; negative values indicate a more El Niño-like state (Yan et al., 2011). (d) Detrended iron intensity record from marine sediment core GeoB 3313-1 on an inverted axis (Lamy et al., 2001). Lower values suggest more humid conditions. Orange error bars indicate published ${ }^{14} \mathrm{C}$ age control points and associated $1 \sigma$ AMS analytical error (F. Lamy, personal communication, 2014). (e) $\delta^{18} \mathrm{O}$ of stalagmite MA1 on an inverted axis. Lower values indicate an increased drip rate, driven by higher precipitation (Schimpf et al., 2011). Green error bars show positions and $2 \sigma$ error of $U / T h$ ages. (f) WAIS Divide coarse particle percentage (this work) on an inverted axis, using timescale WDC06A-7. Data sets are plotted on their own published timescales. Gray bars indicate intervals of inferred southerly position of the SWW in the eastern Pacific, based on our interpretation of the CPP and South American precipitation reconstructions. Red and blue bars indicate the MCA and LIA intervals, respectively. 
under more arid conditions, there is relatively greater input from the iron-rich Andes (Lamy et al., 2001). The GeoB 3313-1 record indicates centennial-scale southward shifts and/or weakening of the SWW with peaks centered on 130, 280 and 1190 CE. Of these, the last event is the longest, spanning $\sim 1110-1395 \mathrm{CE}$ (Fig. 8d). Farther to the south at $53^{\circ} \mathrm{S}$, the Marcelo Arévalo cave is located in the modern core of the summer SWW. The MA1 stalagmite from this cave provides a high-resolution (sub-annual) record of precipitation, recorded in stable oxygen isotopic ratios (Schimpf et al., 2011). The MA1 $\delta^{18} \mathrm{O}$ record suggests that the cave experienced relatively dry conditions during the period $\sim 1120$ $1400 \mathrm{CE}$, with shorter intervals of aridity centered on $\sim 120$ and $\sim 300 \mathrm{CE}$ (Fig. 8e). The intervals of aridity recorded by the Lamy et al. (2001) and Schimpf et al. (2011) records are roughly synchronous, and indicate a decrease in SWWdriven rainfall, caused either by a southward shift or by a weakening of the SWW. Apparent differences in the timing of peak inferred SWW changes are likely an artifact of the records' chronologies. The WAIS Divide WDC06A-7 timescale, used here, is annually resolved with an uncertainty of \pm 1 year (WAIS Divide Project Members, 2013), while the Lamy et al. (2001) and Schimpf et al. (2011) records have 3 and 9 age control points, respectively, over the past 2400 years and assume linear sedimentation rates (see error bars in Fig. 8d, e which represent published uncertainty values for these records' timescales).

The three major intervals of aridity in the Chilean midlatitudes occur at times of enhanced coarse particle deposition at WAIS Divide, interpreted to indicate an increased influence of the SWW via cyclonic storms in the AmundsenBellingshausen Sea region. Taken together, these data suggest that the SWW occupied a more southerly position in the eastern Pacific during the periods $\sim 80-150 \mathrm{CE}, \sim 260$ $310 \mathrm{CE}$, and $\sim 1050-1400 \mathrm{CE}$. The westerlies appear to have shifted to a more northerly position at $\sim 1400-1430 \mathrm{CE}$, remaining there until around 1850-1950 CE. Figure 9 summarizes our interpretations of past changes in SWW position, based on our CPP and hydrological reconstructions from South America.

Wind reconstructions from South Africa are roughly consistent with the timing and direction of changes observed in the eastern Pacific during the past millennium (Stager et al., 2012), while records from Australia and New Zealand are neither consistently in-phase nor out (Knudson et al., 2011; Saunders et al., 2012). Knudson et al. (2011) suggested that in addition to potential changes in the extent and intensity of the SWW belt, the SWW varied zonally, likely due to interactions with atmospheric pressure systems, which shift in response to changes in high-frequency climate oscillations such as the SAM and ENSO. Thus, while millennialscale SH climate changes seem to have been largely synchronous over the Holocene (Fletcher and Moreno, 2012; Kilian and Lamy, 2012), it appears that centennial-scale patterns of atmospheric circulation change during the late Holocene present a more complicated picture.

\subsection{Potential mechanisms of SWW change}

A proposed mechanism for SWW latitudinal change on millennial timescales during the last glacial period and termination invokes cold temperatures in the NH pushing earth's thermal equator southward, displacing the $\mathrm{SH}$ westerlies poleward (Toggweiler et al., 2006; Denton et al., 2010). While there is increasingly strong evidence to support this atmospheric bipolar seesaw mechanism on glacial/interglacial timescales (Kaiser et al., 2005; Lamy et al., 2007; Anderson et al., 2009; Burke and Robinson, 2012; De Deckker et al., 2012; Kohfeld et al., 2013), it is less clear how the SWW respond to climate forcing on decadal-to-centennial timescales, and whether mechanisms of change during the LIA were analogous. During the LIA, atmospheric cooling, which was greater in the NH (Mann et al., 2009), likely drove the ITCZ southward at $\sim 1400 \mathrm{CE}$, where it remained for $\sim 450$ years (Haug et al., 2001; Sachs et al., 2009). Following the mechanism described above, we might expect to see high latitude SH warming and a southward shift of the SWW during the LIA.

However, neither the timing nor direction of inferred change in the SWW is consistent with a $\mathrm{NH}$ temperature signal transmitted through the ITCZ. The Cariaco Basin titanium record indicates that the ITCZ shifted southward at $\sim 1400$ CE (Haug et al., 2001), about the time that South American precipitation reconstructions and our CPP record suggest a northward shift of the SWW and/or intensification in the mid-latitudes (Fig. 8d-f). Moreover, the high-latitude $\mathrm{SH}$ also cooled during the LIA, although to a lesser degree and possibly later than the high-latitude $\mathrm{NH}$, which started to cool as early as $1150 \mathrm{CE}$ (Lowell et al., 2013). Ice core and marine sediment core records suggest cooling of both surface air temperature in West Antarctica (Orsi et al., 2012) and sea surface temperature (SST) on the western side of the Antarctic Peninsula (WAP; Shevenell, et al., 2011), respectively. In addition, a record of moss growth from Anvers Island, WAP, indicates that glaciers expanded around $1300 \mathrm{CE}$ (Hall et al., 2010), the same time that temperature cooled in the McMurdo Sound region (Bertler et al., 2011). Therefore, it does not appear likely that the documented changes in the ITCZ drove warming and a southward shift of the SWW during the NH LIA.

Modeling studies suggest that changes in solar variability can exert a significant influence on SWW variability, through both so-called "bottom-up" and "top-down" mechanisms (Varma et al., 2011, 2012). The "bottom-up" mechanism relies on the absorption of shortwave radiation at the surface and related feedbacks, whereas the "top-down" mechanism is driven by the stratospheric ozone response to changes in ultraviolet radiation (Varma et al., 2011). Total solar irradiance (TSI), reconstructed from variations in ${ }^{10} \mathrm{Be}$ and ${ }^{14} \mathrm{C}$, 


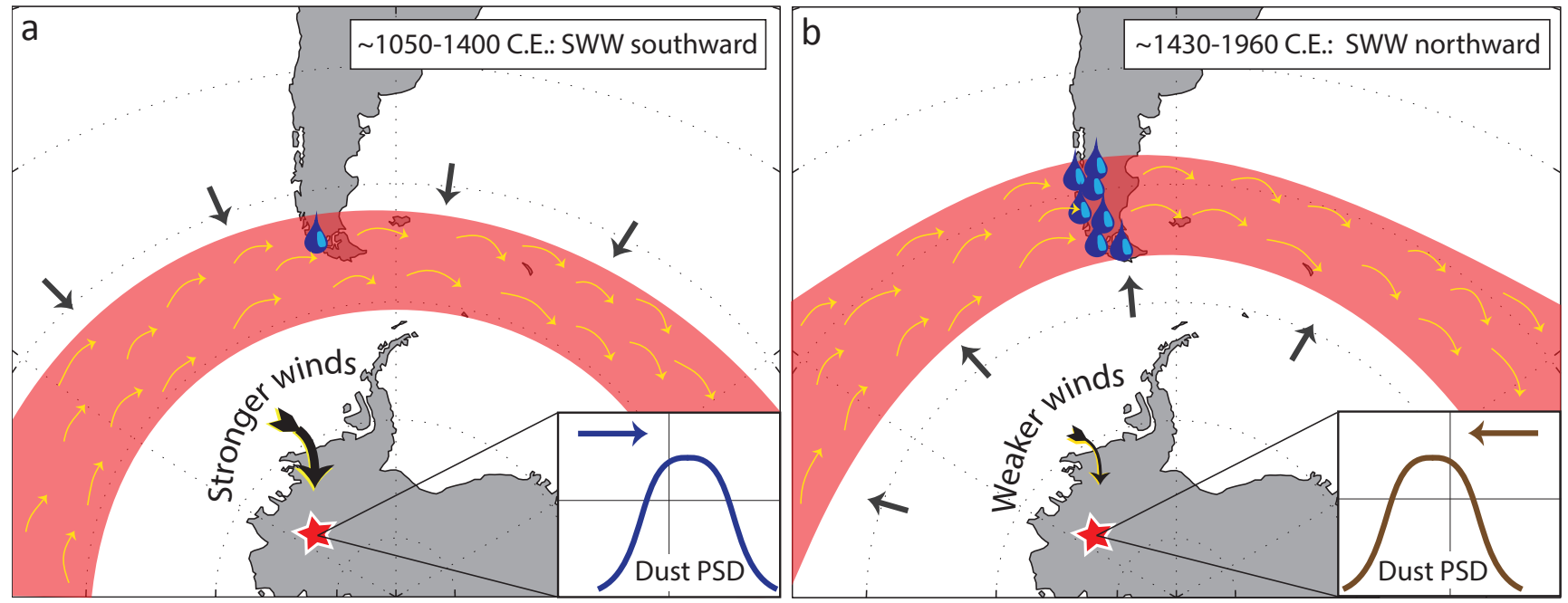

Figure 9. Schematic diagram showing interpretation of paleoclimate records. (a) During the interval 1050-1400 CE, the SWW are shifted southward, reducing precipitation in the SH mid-latitudes and driving greater cyclogenesis in the Amundsen-Bellingshausen Sea region; stronger winds in turn carry dust with a coarser particle size distribution (PSD). (b) From 1430-1960 CE, the SWW occupy a more northerly position, enhancing precipitation in the SH mid-latitudes and reducing cyclogenesis and wind speed in the WAIS Divide region; weaker winds in turn transport dust with a finer PSD.

has varied by about $\pm 1 \mathrm{Wm}^{-2}$ during the Holocene, enough to have had an appreciable impact on climate (Solanki et al., 2004; Steinhilber et al., 2009). Varma et al. (2011) compared the Lamy et al. (2001) Fe record with TSI reconstructions, and found that inferred latitudinal shifts in the SWW correlated with changes in solar variability $(r=0.45$ and $r=0.21$ for the ${ }^{10} \mathrm{Be}$ - and ${ }^{14} \mathrm{C}$-based reconstructions, respectively). Although there appears to be reasonably good correspondence between reconstructed TSI (Fig. 8a) and various proxies for the SWW, including the CPP (Fig. 8f), the relative timing of changes is not completely consistent (see also Fig. 12, Kilian and Lamy, 2012).

The tropical Pacific exerts a strong influence on the highlatitude $\mathrm{SH}$, through atmospheric circulation changes related both to ENSO and to non-ENSO SST anomalies (e.g., Schneider and Gies, 2004; Lachlan-Cope and Connolley, 2006; Schneider and Steig, 2008; Lamy et al., 2010; Ding et al., 2011, 2012; Schneider et al., 2012). Signals propagate to the high latitudes via two primary mechanisms: (1) the Pacific-South America pattern, interpreted as a Rossby wave train originating in the tropics, and (2) zonal wind anomalies which are thermally driven in the tropics and eddy-driven in the mid- and high latitudes (Schneider et al., 2012, and references therein). Schneider and Gies (2004) found that El Niño events were associated with decreased precipitation in the Chilean mid-latitudes, a pattern attributed to weaker westerly winds in this region. These observations are consistent with the proxy reconstructions discussed here, which show that periods of aridity are coincident with intervals of increased El Niño frequency (Fig. 8b-f). Schneider and Steig (2008) and Ding et al. (2011) found that SST anomalies in the central tropical Pacific led to shifts in atmospheric circulation patterns in the Amundsen-Bellingshausen Sea region, causing advection of warm air over central West Antarctica. While we do not see annual-scale events in the CPP record that can be attributed to ENSO activity, we do observe enhanced coarse particle deposition during intervals of prolonged $\mathrm{El}$ Niño-like conditions during the past 2400 years, as evidenced by lake- and marine-based reconstructions (Fig. 8b, c; Moy et al., 2002; Yan et al., 2011). Indeed, the correspondence of ENSO and SWW reconstructions over the past 2400 years is consistent with a strong role of the tropical Pacific in forcing high-latitude SH climate.

\section{Conclusions}

We present the first high-resolution microparticle data set from West Antarctica, spanning the past 2400 years (430 BCE to $2002 \mathrm{CE}$ ). We find a particle grain size distribution with a mode diameter in the range of 5-8 $\mu \mathrm{m}$, comparable to other Antarctic non-EAIS plateau sites. The relative coarseness of particles found in lower-elevation and coastal sites suggests that dust deposited in much of Antarctica has a grain size signature that differs from that of central East Antarctica. Given the relatively coarse size distribution at WAIS Divide, and the similarity in the dust PSD to the theoretical dust emission PSD (Kok, 2011a, b), we infer that there must be an Antarctic dust source supplying central West Antarctica, in addition to potential distal sources such as Australia. Late Holocene dust flux to the WAIS Divide site has remained fairly constant at $\sim 3-5 \mathrm{mg} \mathrm{m}^{-2}$ year $^{-1}$, intermediate between coastal sites in the Weddell Sea region and 
sites located on the East Antarctic plateau. Observed dust flux differences seem to be driven in part by particle size, which may reflect dust emissions activity near the margins of the Antarctic continent. Further, flux and grain size differences among sites suggest that a substantial amount of dust is transported below $\sim 3000 \mathrm{~m}$ and does not reach the EAIS plateau.

Based on significant positive correlations with midlatitude zonal and meridional wind speeds and supported by terrestrial and marine proxy data from the northern edge to the core of the SWW belt, we suggest that changes in the PSD indicate variability in atmospheric circulation intensity in the Amundsen-Bellingshausen Sea region. We infer that the SWW belt in the eastern Pacific shifted poleward during three intervals in the past 2400 years: $\sim 80-150, \sim 260$ 310 , and $\sim 1050-1430 \mathrm{CE}$, and that it shifted equatorward around 1400-1430 CE, where it remained during the NH LIA ( 1400-1850 CE). We suggest that these changes occurred in response to both surface temperature changes in the tropical Pacific and solar variability. Therefore, it seems possible that the SWW respond to different forcings on different timescales, a condition that may be necessary to reconcile late Holocene and glacial/interglacial SWW reconstructions.

Acknowledgements. We appreciate helpful discussion with Samuel Albani, Gordon Bromley, Alejandra Borunda, Barbara Delmonte, Gang Chen, Yael Kiro, Jasper Kok, Natalie Mahowald, and Eric Steig. Dianne Dietrich, Jasper Kok, Mark Neary and Huijie Xue helped with software development. We thank Rich Pawlowicz for the $\mathrm{m} \_$map plotting package, M. Ma for the wind_rose.m program, Greg Gerbi for help with data filtering, and Urs Ruth and Anna Wegner for assistance setting up and calibrating the Abakus particle counter. David Bromwich and Julien Nicolas provided helpful insights on regional winds and reanalysis data. This paper was improved by helpful comments from Toby Koffman, Stephen Norton, Urs Ruth, and Roberto Udisti. We thank the WAIS Divide Science Coordination Office, Ice Drilling Design and Operations group, the National Ice Core Laboratory, Raytheon Polar Services Company, and the 109th New York Air National Guard. We appreciate the support of the University of Wisconsin-Madison Automatic Weather Station Program for the AWS data set, NSF grant ANT0944018. This research was funded by NSF grant ANT-0636740, and by the University of Maine Chase Distinguished Research Assistantship, Correll Graduate Student Research Fellowship, and Dissertation Research Fellowship to B. G. Koffman. We thank two anonymous reviewers, whose thoughtful suggestions and questions served to clarify and improve the paper.

Edited by: A. N. LeGrande and G. Winckler

\section{References}

Albani, S., Mahowald, N. M., Delmonte, B., Maggi, V., and Winckler, G.: Comparing modeled and observed changes in mineral dust transport and deposition to Antarctica between the
Last Glacial Maximum and current climates, Clim. Dynam., 38, 1731-1755, doi:10.1007/s00382-011-1139-5, 2011.

Albani, S., Delmonte, B., Maggi, V., Baroni, C., Petit, J.-R., Stenni, B., Mazzola, C., and Frezzotti, M.: Interpreting last glacial to Holocene dust changes at Talos Dome (East Antarctica): implications for atmospheric variations from regional to hemispheric scales, Clim. Past, 8, 741-750, doi:10.5194/cp-8-7412012, 2012.

Anderson, R. F., Ali, S., Bradtmiller, L. I., Nielsen, S. H. H., Fleisher, M. Q., Anderson, B. E., and Burckle, L. H.: Wind-driven upwelling in the Southern Ocean and the deglacial rise in atmospheric $\mathrm{CO}_{2}$, Science, 323, 1443-1448, doi:10.1126/science.1167441, 2009.

Arblaster, J. M. and Meehl, G. A.: Contributions of external forcings to Southern Annular Mode trends, J. Climate, 19, 28962905, 2006.

Banta, J. R., McConnell, J. R., Frey, M. M., Bales, R. C., and Taylor, K. C.: Spatial and temporal variability in snow accumulation at the West Antarctic Ice Sheet Divide over recent centuries, J. Geophys. Res., 113, D23102, doi:10.1029/2008JD010235, 2008.

Basile, I., Grousset, F. E., Revel, M., Petit, J. R., Biscaye, P. E., and Barkov, N. I.: Patagonian origin of glacial dust deposited in East Antarctica (Vostok and Dome C) during glacial stages 2, 4 and 6, Earth Planet. Sci. Lett., 146, 573-589, 1997.

Bertler, N. A. N., Mayewski, P., Aristarain, A. J., Barrett, P., Becagli, S., Bernardo, R., Bo, S., Xiao, C., Curran, M., Qin, D., Dixon, D. A., Ferron, F., Fischer, H., Frey, M., Frezzotti, M., Fundel, F., Genthon, C., Gragnani, R., Hamilton, G., Handley, M., Hong, S., Isaksson, E., Kang, J., Ren, J., Kamiyama, K., Kanamori, S., Karkas, E., Karlof, L., Kaspari, S., Kreutz, K., Kurbatov, A., Meyerson, E., Ming, Y., Zhang, M., Motoyama, H., Mulvaney, R., Oerter, H., Osterberg, E., Proposito, M., Pyne, A., Ruth, U., Simoes, J. C., Smith, B., Sneed, S. B., Teinila, K., Traufetter, F., Udisti, R., Virkkula, A., Watanabe, O., Wiliamson, B., Winther, J.-G., Li, Y., Wolff, E., Li, Z., and Zielinski, A.: Snow chemistry across Antarctica, Ann. Glaciol., 41, 167-179, 2005.

Bertler, N. A. N., Mayewski, P., and Carter, L.: Cold conditions in Antarctica during the Little Ice Age - Implications for abrupt climate change mechanisms, Earth Planet. Sci. Lett., 308, 41-51, doi:10.1016/j.eps1.2011.05.021, 2011.

Björck, S., Rundgren, M., Ljung, K., Unkel, I., and Wallin, Å.: Multi-proxy analyses of a peat bog on Isla de los Estados, Easternmost Tierra del Fuego: a unique record of the variable Southern Hemisphere westerlies since the last deglaciation, Quaternary Sci. Rev., 42, 1-14, doi:10.1016/j.quascirev.2012.03.015, 2012.

Bory, A. J.-M., Wolff, E., Mulvaney, R., Jagoutz, E., Wegner, A., Ruth, U., and Elderfield, H.: Multiple sources supply eolian mineral dust to the Atlantic sector of coastal Antarctica: Evidence from recent snow layers at the top of Berkner Island ice sheet, Earth Planet. Sci. Lett., 291, 138-148, doi:10.1016/j.eps1.2010.01.006, 2010.

Breton, D. J., Koffman, B. G., Kurbatov, A. V., Kreutz, K. J., and Hamilton, G. S.: Quantifying Signal Dispersion in a Hybrid Ice Core Melting System, Environ. Sci. Technol., 46, 11922-11928, doi:10.1021/es302041k, 2012.

Burke, A. and Robinson, L. F.: The Southern Ocean's role in carbon exchange during the last deglaciation, Science, 335, 557-561, 2012. 
De Deckker, P., Moros, M., Perner, K., and Jansen, E.: Influence of the tropics and southern westerlies on glacial interhemispheric asymmetry, Nat. Geosci., 5, 266-269, doi:10.1038/NGEO1431, 2012

Dee, D. P., Uppala, S. M., Simmons, A. J., Berrisford, P., Poli, P., Kobayashi, S., Andrae, U., Balmaseda, M. A., Balsamo, G., Bauer, P., Bechtold, P., Beljaars, A. C. M., van de Berg, L., Bidlot, J., Bormann, N., Delsol, C., Dragani, R., Fuentes, M., Geer, A. J., Haimberger, L., Healy, S. B., Hersbach, H., Holm, E. V., Isaksen, L., Kallberg, P., Kohler, M., Matricardi, M., McNally, A. P., Monge-Sanz, B. M., Morcrette, J.-J., Park, B.-K., Peubey, C., de Rosnay, P., Tavolato, C., Thepaut, J.-N., and Vitart, F.: The ERA-Interim reanalysis: configuration and performance of the data assimilation system, Q. J. Roy. Meteorol. Soc., 137, 553597, 2011

Delmonte, B., Petit, J.-R., and Maggi, V.: Glacial to Holocene implications of the new 27,000-year dust record from the EPICA Dome C (East Antarctica) ice core, Clim. Dynam., 18, 647-660, doi:10.1007/s00382-001-0193-9, 2002.

Delmonte, B., Basile-Doelsch, I., Petit, J. R., Maggi, V., RevelRolland, M., Michard, A., Jagoutz, E., and Grousset, F.: Comparing the Epica and Vostok dust records during the last 220,000 years: stratigraphical correlation and provenance in glacial periods, Earth-Sci. Rev., 66, 63-87, 2004.

Delmonte, B., Petit, J. R., Krinner, G., Maggi, V., Jouzel, J., and Udisti, R.: Ice core evidence for secular variability and 200-year dipolar oscillations in atmospheric circulation over East Antarctica during the Holocene, Clim. Dynam., 24, 641-654, 2005.

Delmonte, B., Andersson, P. S., Hansson, M., Schoberg, H., Petit, J. R., Basile-Doelsch, I., and Maggi, V.: Aeolian dust in East Antarctica (EPICA-Dome C and Vostok): Provenance during glacial ages of the last $800 \mathrm{kyr}$, Geophys. Res. Lett., 35, L07703, doi:10.1029/2008GL033382, 2008.

Delmonte, B., Andersson, P. S., Schoberg, H., Hansson, M., Petit, J. R., Delmas, R., Gaiero, D. M., Maggi, V., and Frezzotti, M.: Geographic provenance of aeolian dust in East Antarctica during Pleistocene glaciations: preliminary results from Talos Dome and comparison with East Antarctic and new Andean ice core data, Quaternary Sci. Rev., 29, 256-264, doi:10.1016/j.quascirev.2009.05.010, 2010.

Denton, G. H., Anderson, R. F., Toggweiler, J. R., Edwards, R. L., Schaefer, J. M., and Putnam, A. E.: The last glacial termination, Science, 328, 1652-1656, 2010.

Ding, Q., Steig, E., Battisti, D. S., and Kuttel, M.: Winter warming in West Antarctica caused by central tropical Pacific warming, Nat. Geosci., 4, 398-403, doi:10.1038/NGEO1129, 2011.

Ding, Q., Steig, E. J., Battisti, D. S., and Wallace, J. M.: Influence of the Tropics on the Southern Annular Mode, J. Climate, 25, 6330-6348, doi:10.1175/JCLI-D-11-00523.1, 2012.

Ding, Z. L., Derbyshire, E., Yang, S. L., Yu, Z. W., Xiong, S. F., and Liu, T. S.: Stacked 2.6-Ma grain size record from the Chines loess based on five sections and correlation with the deep-see $\delta^{18} \mathrm{O}$ record, Paleoceanography, 17, doi:10.1029/2001PA000725, 2002.

Dixon, D. A., Mayewski, P. A., Goodwin, I. D., Marshall, G. J., Freeman, R., Maasch, K. A., and Sneed, S.: An ice core proxy for northerly air mass incursions (NAMI) into West Antarctica, Int. J. Climatol., 32, 1455-1465, doi:10.1002/joc.2371, 2012.
Edwards, R., Sedwick, P., Morgan, V., and Boutron, C.: Iron in ice cores from Law Dome: A record of atmospheric iron deposition for maritime East Antarctica during the Holocene and Last Glacial Maximum, Geochem. Geophys. Geosys., 7, Q12Q01, doi:10.1029/2006GC001307, 2006.

Fischer, H., Siggaard-Andersen, M.-L., Ruth, U., Rothlisberger, R., and Wolff, E.: Glacial/interglacial changes in mineral dust and sea-salt records in polar ice cores: sources, transport, and deposition, Rev. Geophys., 45, RG1002, doi:10.1029/2005RG000192, 2007.

Fletcher, M.-S. and Moreno, P. I.: Zonally symmetric changes in the strength and position of the Southern westerlies drove atmospheric $\mathrm{CO}_{2}$ variations over the past 14 k.y. Geology, 39, 419422, doi:10.1130/G31807.1, 2011.

Fletcher, M.-S. and Moreno, P. I.: Have the southern westerlies changed in a zonally symmetric manner over the last 14,000 years? A hemisphere-wide take on a controversial problem, Quaternary Int., 253, 32-46, doi:10.1016/j.quaint.2011.04.042, 2012.

Gaspari, V., Barbante, C., Cozzi, G., Cescon, P., Boutron, C. F., Gabrielli, P., Capodaglio, G., Ferrari, C., Petit, J. R., and Delmonte, B.: Atmospheric iron fluxes over the last deglaciation: Climatic implications, Geophys. Res. Lett., 33, L03704, doi:10.1029/2005GL024352, 2006.

Goodwin, I. D., van Ommen, T. D., Curran, M. A. J., and Mayewski, P. A.: Mid latitude winter climate variability in the South Indian and southwest Pacific regions since $1300 \mathrm{AD}$, Clim. Dynam., 22, 783-794, doi:10.1007/s00382-004-0403-3, 2004.

Goodwin, I. D., Browning, S., Lorrey, A. M., Mayewski, P. A., Phipps, S. J., Bertler, N. A. N., Edwards, R. P., Cohen, T. J., van Ommen, T., Curran, M., Barr, C., and Stager, J. C.: A reconstruction of extratropical Indo-Pacific sea-level pressure patterns during the Medieval Climate Anomaly, Clim. Dynam., 123, doi:10.1007/s00382-013-1899-1, 2013.

Hall, B. L., Koffman, T., and Denton, G. H.: Reduced ice extent on the western Antarctic Peninsula at 700-970 cal. yr B.P., Geology, 38, 635-638, doi:10.1130/G30932.1, 2010.

Haug, G. H., Hughen, K. A., Sigman, D. M., Peterson, L. C., and Rohl, U.: Southward migration of the intertropical convergence zone through the Holocene, Science, 293, 1304-1308, 2001.

Ho, M., Kiem, A. S., and Verdon-Kidd, D. C.: The Southern Annular Mode: a comparison of indices, Hydrol. Earth Syst. Sci., 16, 967-982, doi:10.5194/hess-16-967-2012, 2012.

Jones, J. L., Fogt, R. L., Widmann, M., Marshall, G. J., Jones, P. D., and Visbeck, M.: Historical SAM Variability. Part 1: Century-length seasonal reconstructions, J. Climate, 22, 53195345, doi:10.1175/2009JCLI2785.1, 2009.

Kaiser, J., Lamy, F., and Hebbeln, D.: A 70-kyr sea surface temperature record off southern Chile (Ocean Drilling Program Site 1233), Paleoceanography, 20, PA4009, doi:10.1029/2005PA001146, 2005.

Kilian, R. and Lamy, F.: A review of Glacial and Holocene paleoclimate records from southernmost Patagonia (49-55 $\left.{ }^{\circ} \mathrm{S}\right)$, Quaternary Sci. Rev., 53, 1-23, doi:10.1016/j.quascirev.2012.07.017, 2012.

Knudson, K. P., Hendy, I. L., and Neil, H. L.: Re-examining Southern Hemisphere westerly wind behavior: insights from a late Holocene precipitation reconstruction using New Zealand fjord sediments, Quaternary Sci. Rev., 30, 3124-3138, doi:10.1016/j.quascirev.2011.07.017, 2011. 
Kohfeld, K. E., Graham, R. M., de Boer, A. M., Sime, L. C., Wolff, E. W., Le Quéré, C., and Bopp, L.: Southern Hemisphere westerly wind changes during the Last Glacial Maximum: paleo-data synthesis, Quaternary Sci. Rev., 68, 76-95, doi:10.1016/j.quascirev.2013.01.017, 2013.

Kok, J. F.: A scaling theory for the size distribution of emitted dust aerosols suggests climate models underestimate the size of the global dust cycle, Proc. Natl. Acad. Sci. USA, 108, 1016-1021, doi:10.1073/pnas.1014798108, 2011a.

Kok, J. F.: Does the size distribution of mineral dust aerosols depend on the wind speed at emission?, Atmos. Chem. Phys., 11, 1014910156, doi:10.5194/acp-11-10149-2011, 2011b.

Kreutz, K. J., Mayewski, P. A., Meeker, L. D., Twickler, M. S., Whitlow, S. I., and Pittalwala, I. I.: Bipolar changes in atmospheric circulation during the Little Ice Age, Science, 277, 12941296, 1997.

Kreutz, K. J., Mayewski, P. A., Meeker, L. D., Twickler, M. S., and Whitlow, S. I.: The effect of spatial and temporal accumulation rate variability in West Antarctica on soluble ion deposition, Geophys. Res. Lett., 27, 2517-2520, 2000a.

Kreutz, K. J., Mayewski, P. A., Pittalwala, I. I., Meeker, L. D., Twickler, M. S., and Whitlow, S. I.: Sea level pressure variability in the Amundsen Sea region inferred from a West Antarctic glaciochemical record, J. Geophys. Res., 105, 4047-4059, 2000b.

Krinner, G., Petit, J.-R., and Delmonte, B.: Altitude of atmospheric trace transport toward Antarctica in present and glacial climate, Quaternary Sci. Rev., 29, 274-284, doi:10.1016/j.quascirev.2009.06.020, 2010.

Lachlan-Cope, T. and Connolley, W.: Teleconnections between the tropical Pacific and the Amundsen-Bellingshausens Sea: Role of the El Nino/Southern Oscillation, J. Geophys. Res., 111, D23101, doi:10.1029/2005JD006386, 2006.

Lambert, F., Delmonte, B., Petit, J.-R., Bigler, M., Kaufmann, P., Hutterli, M. A., Stocker, T., and Ruth, U.: Dust-climate couplings over the past 800,000 years from the EPICA Dome C ice core, Nature, 452, 616-619, doi:10.1038/nature06763, 2008.

Lambert, F., Bigler, M., Steffensen, J. P., Hutterli, M., and Fischer, H.: Centennial mineral dust variability in high-resolution ice core data from Dome C, Antarctica, Clim. Past, 8, 609-623, doi:10.5194/cp-8-609-2012, 2012.

Lamy, F., Hebbeln, D., Rohl, U., and Wefer, G.: Holocene rainfall variability in southern Chile: a marine record of latitudinal shifts of the southern westerlies, Earth Planet. Sci. Lett., 185, 369-382, 2001.

Lamy, F., Kaiser, J., Arz, H. W., Hebbeln, D., Ninnemann, U. S., Timm, O., Timmerman, A., and Toggweiler, J. R.: Modulation of the bipolar seesaw in the Southeast Pacific during Termination 1, Earth Planet. Sci. Lett., 259, 400-413, doi:10.1016/j.epsl.2007.04.040, 2007.

Lamy, F., Kilian, R., Arz, H. W., Francois, J.-P., Kaiser, J., Prange, M., and Steinke, T.: Holocene changes in the position and intensity of the southern westerly wind belt, Nat. Geosci., 3, 695-699, 2010.

Lazzara, M. A., Weidner, G. A., Keller, L. M., Thom, J. E., and Cassano, J. J.: Antarctic Automatic Weather Station Program: 30 years of polar observations, B. Am. Meteorol. Soc., 93, 15191537, 2012.
Lee, S. and Feldstein, S. B.: Detecting ozone- and greenhouse gasdriven wind trends with observational data, Science, 339, 563567, 2013.

Legrand, M. and Mayewski, P.: Glaciochemistry of polar ice cores: A review, Rev. Geophys., 35, 219-243, 1997.

Lenton, A., Codron, F., Bopp, L., Metzl, N., Cadule, P., Tagliabue, A., and Le Sommer, J.: Stratospheric ozone depletion reduces ocean carbon uptake and enhances ocean acidification, Geophys. Res. Lett., 36, L12606, doi:10.1029/2009GL038227, 2009.

Lenton, A., Metzl, N., Takahashi, T., Kuchinke, M., Matear, R. J., Roy, T., Sutherland, S. C., Sweeney, C., and Tilbrook, B.: The observed evolution of oceanic $p \mathrm{CO}_{2}$ and its drivers over the last two decades, Global Biogeochem. Cy., 26, GB2021, doi:10.1029/2011GB004095, 2012.

Li, F., Ginoux, P., and Ramaswamy, V.: Distribution, transport, and depositon of mineral dust in the Southern Ocean and Antarctica: Contribution of major sources, J. Geophys. Res., 113, D10207, doi:10.1029/2007JD009190, 2008.

Lowell, T. V., Hall, B. L., Kelly, M. A., Bennike, O., Lusas, A. R., Honsaker, W., Smith, C. A., Levy, L. B., Travis, S., and Denton, G. H.: Late Holocene expansion of Istorvet ice cap, Liverpool Land, east Greenland, Quaternary Sci. Rev., 63, 128-140, doi:10.1016/j.quascirev.2012.11.012, 2013.

Lubin, D., Wittenmyer, R. A., Bromwich, D. H., and Marshall, G. J.: Antarctic Peninsula mesoscale cyclone variability and climatic impacts influenced by the SAM, Geophys. Res. Lett., 35, L02808, doi:10.1029/2007GL032170, 2008.

Maasch, K. A., Mayewski, P. A., Rohling, E. J., Stager, J. C., Karlen, W., Meeker, L. D., and Meyerson, E. A.: A 2000-year context for modern climate change, Geograf. Ann., 87A, 7-15, 2005.

Mann, M. E., Zhang, Z., Hughes, M. K., Bradley, R. S., Miller, S. K., Rutherford, S., and Ni, F.: Proxy-based reconstructions of hemispheric and global surface temperature variations over the past two millennia, Proc. Natl. Acad. Sci. USA, 105, 1325213257, doi:10.1073/pnas.0805721105, 2008.

Mann, M. E., Zhang, Z., Rutherford, S., Bradley, R. S., Hughes, M. K., Shindell, D. T., Ammann, C., Faluvegi, G., and Ni, F.: Global signatures and dynamical origins of the Little Ice Age and Medieval Climate Anomaly, Science, 326, 1256-1260, doi:10.1126/science.1177303, 2009.

Marino, F., Castellano, E., Ceccato, D., De Deckker, P., Delmonte, B., Ghermandi, G., Maggi, V., Petit, J. R., Revel-Rolland, M., and Udisti, R.: Defining the geochemical composition of the EPICA Dome $\mathrm{C}$ ice core dust during the last glacialinterglacial cycle, Geochem. Geophys. Geosys., 9, Q10018, doi:10.1029/2008GC002023, 2008.

Marino, F., Castellano, E., Nava, S., Chiari, M., Ruth, U., Wegner, A., Lucarelli, F., Udisti, R., Delmonte, B., and Maggi, V.: Coherent composition of glacial dust on opposite sides of the East Antarctic Plateau inferred from the deep EPICA ice cores, Geophys. Res. Lett., 36, L23703, doi:10.1029/2009GL040732, 2009.

Marshall, G. J.: Trends in the Southern Annular Mode from Observations and Reanalyses, J. Climate, 16, 4134-4143, 2003.

Martinez-Garcia, A., Rosell-Mele, A., Jaccard, S. L., Geibert, W., Sigman, D. M., and Haug, G. H.: Southern Ocean dust-climate coupling over the past four million years, Nature, 476, 312-315, 2011. 
Mayewski, P., Maasch, K. A., Dixon, D. A., Sneed, S. B., Oglesby, R., Korotkikh, E., Potocki, M., Grigholm, B., Kreutz, K., Kurbatov, A., Spaulding, N., Stager, J. C., Taylor, K. C., Steig, E., White, J., Bertler, N. A. N., Goodwin, I., Simoes, J. C., Jana, R., Kraus, S., and Fastook, J.: West Antarctica's sensitivity to natural and human-forced climate change over the Holocene, J. Quaternary Sci., 28, 40-48, 2013.

Mayewski, P. A., Meeker, L. D., Whitlow, S. I., Twickler, M. S., Morrison, M. C., Grootes, P. M., Bond, G. C., Alley, R. B., Meese, D. A., Gow, A. J., Taylor, K. C., Ram, M., and Wumkes, M.: Changes in atmospheric circulation and ocean ice cover over the North Atlantic during the last 41,000 years, Science, 263, 1747-1751, 1994.

Mayewski, P. A., Meredith, M., Summerhayes, C., Turner, J., Aoki, S., Barrett, P., Bertler, N. A. N., Bracegirdle, T., Bromwich, D., Campbell, H., Casassa, G., Garabato, A. N., Lyons, W. B., Maasch, K. A., Worby, A., and Xiao, C.: State of the Antarctic and Southern Ocean Climate System, Rev. Geophys., 47, RG1003, doi:10.1029/2007RG000231, 2009.

McConnell, J. R., Aristarain, A. J., Banta, J. R., Edwards, P. R., and Simoes, J. C.: 20th-Century doubling in dust archived in an Antarctic Peninsula ice core parallels climate change and desertification in South America, Proc. Natl. Acad. Sci. USA, 104, 5743-5748, 2007.

McGee, D., Broecker, W. S., and Winckler, G.: Gustiness: The driver of glacial dustiness?, Quaternary Sci. Rev., 29, 2340 2350, 2010.

Moreno, P. I., Francois, J. P., Villa-Martinez, R. P., and Moy, C. M.: Millennial-scale variability in Southern Hemisphere westerly wind activity over the last 5000 years in SW Patagonia, Quaternary Sci. Rev., 28, 25-38, doi:10.1016/j.quascirev.2008.10.009, 2009.

Moreno, P. I., Francois, J. P., Moy, C. M., and Villa-Martinez, R.: Covariability of the Southern Westerlies and atmospheric $\mathrm{CO}_{2}$ during the Holocene, Geology, 38, 727-730, 2010.

Moy, C. M., Seltzer, G. O., Rodbell, D. T., and Anderson, D. M.: Variability of El Nino/Southern Oscillation activity at millennial timescales during the Holocene epoch, Nature, 420, 162-165, 2002

Nicolas, J. P. and Bromwich, D. H.: Climate of West Antarctica and influence of marine air intrusions, J. Climate, 24, 49-67, doi:10.1175/2010JCLI3522.1, 2011.

Orsi, A. J., Cornuelle, B. D., and Severinghaus, J. P.: Little Ice Age cold interval in West Antarctica: Evidence from borehole temperature at the West Antarctic Ice Sheet (WAIS) Divide, Geophys. Res. Lett., 39, L09710, doi:10.1029/2012GL051260, 2012.

Petit, J. R., Jouzel, J., Raynaud, D., Barkov, N. I., Barnola, J. M., Basile, I., Bender, M., Chappellaz, J., Davis, M., Delaygue, G., Delmotte, M., Kotlyakov, V. M., Legrand, M., Lipenkov, V. Y., Lorius, C., Pepin, L., Ritz, C., Saltzman, E., and Stievenard, M.: Climate and atmospheric history of the past 420,000 years from the Vostok ice core, Antarctica, Nature, 399, 429-436, 1999.

Rankin, A. M., Wolff, E., and Martin, S.: Frost flowers: implications for tropospheric chemistry and ice core interpretation, J. Geophys. Res., 107, 4683, doi:10.1029/2002JD002492, 2002.

Rankin, A. M., Auld, V., and Wolff, E. W.: Frost flowers as a source of fractionated sea salt aerosol in the polar regions, Geophys. Res. Lett., 27, 3469-3472, 2000.
Renssen, H., Goosse, H., Fichefet, T., Masson-Delmotte, V., and Koc, N.: Holocene climate evolution in the high-latitude Southern Hemisphere simulated by a coupled atmospheresea ice-ocean-vegetation model, The Holocene, 15, 951-964, doi:10.1191/0959683605hl869ra, 2005.

Revel-Rolland, M., De Deckker, P., Delmonte, B., Hesse, P. P., Magee, J. W., Basile-Doelsch, I., Grousset, F., and Bosch, D.: Eastern Australia: A possible source of dust in East Antarctica interglacial ice, Earth Planet. Sci. Lett., 249, 1-13, 2006.

Russell, J. L., Dixon, K. W., Gnanadesikan, A., Stouffer, R. J., and Toggweiler, J. R.: The Southern Hemisphere westerlies in a warming world: Propping open the door to the deep ocean, J. Climate, 19, 6382-6390, 2006.

Ruth, U., Wagenbach, D., Steffensen, J. P., and Bigler, M.: Continuous record of microparticle concentration and size distribution in the central Greenland NGRIP ice core during the last glacial period, J. Geophys. Res., 108, 4098, doi:10.1029/2002JD002376, 2003.

Ruth, U., Wagenbach, D., Mulvaney, R., Oerter, H., Graf, W., Pulz, H., and Littot, G.: Comprehensive 1000 year climatic history from an intermediate-depth ice core from the south dome of Berkner Island, Antarctica: methods, dating and first results, Ann. Glaciol., 39, 146-154, 2004.

Ruth, U., Barbante, C., Bigler, M., Delmonte, B., Fischer, H., Gabrielli, P., Gaspari, V., Kaufmann, P., Lambert, F., Maggi, V., Marino, F., Petit, J.-R., Udisti, R., Wagenbach, D., Wegner, A., and Wolff, E. W.: Proxies and Measurement Techniques in Antarctic Ice Cores, Environ. Sci. Technol., 42, 5675-5681, doi:10.1021/es703078z, 2008.

Sachs, J. P., Sachse, D., Smittenberg, R. H., Zhang, Z., Battisti, D. S., and Golubic, S: Southward movement of the Pacific intertropical convergence zone AD 1400-1850, Nat. Geosci., 2, 519-525, doi:10.1038/NGEO554, 2009.

Saunders, K. M., Kamenik, C., Hodgson, D. A., Hunziker, S., Siffert, L., Fischer, D., Fujak, M., Gibson, J. A. E., and Grosjean, M.: Late Holocene changes in precipitation in northwest Tasmania and their potential links to shifts in the Southern Hemisphere westerly winds, Global Planet. Change, 92-93, 82-91, doi:10.1016/j.glopacha.2012.04.005, 2012.

Schimpf, D., Kilian, R., Kronz, A., Simon, K., Spötl, C., Wörner, G., Deininger, M., and Mangini, A.: The significance of chemical, isotopic, and detrital components in three coeval stalagmites from the superhumid southernmost Andes $\left(53^{\circ} \mathrm{S}\right)$ as highresolution palaeo-climate proxies, Quaternary Sci. Rev., 30, 443 459, 2011.

Schneider, C. and Gies, D.: Effects of El Nino-Southern Oscillation on southernmost South America precipitation at $53 \mathrm{deg}$. S revealed from NCEP-NCAR reanalyses and weather station data, Int. J. Climatol., 24, 1057-1076, doi:10.1002/joc.1057, 2004.

Schneider, D. P. and Steig, E. J.: Ice cores record significant 1940s Antarctic warmth related to tropical climate variability, Proc. Natl. Acad. Sci. USA, 105, 12154-12158, 2008.

Schneider, D. P., Okumura, Y., and Deser, C.: Observed Antarctic interannual climate variability and tropical linkages, J. Climate, 25, 4048-4066, doi:10.1175/JCLI-D-11-00273.1, 2012. 
Shevenell, A. E., Ingalls, A. E., Domack, E. W., and Kelly, C.: Holocene Southern Ocean surface temperature variability west of the Antarctic Peninsula, Nature, 470, 250-254, doi:10.1038/nature09751, 2011.

Solanki, S. K., Usoskin, I. G., Kromer, B., Schüssler, M., and Beer, J.: Unusual activity of the Sun during recent decades compared to the previous 11,000 years, Nature, 431, 1084-1087, 2004.

Souney, J. M., Mayewski, P. A., Goodwin, I. D., Meeker, L. D., Morgan, V. I., Curran, M. A. J., van Ommen, T. D., and Palmer, A. S.: A 700-year record of atmospheric circulation developed from the Law Dome ice core, East Antarctica, J. Geophys. Res., 107, 4608, doi:10.1029/2002JD002104, 2002.

Stager, J. C., Mayewski, P. A., White, J., Chase, B. M., Neumann, F. H., Meadows, M. E., King, C. D., and Dixon, D. A.: Precipitation variability in the winter rainfall zone of South Africa during the last $1400 \mathrm{yr}$ linked to the austral westerlies, Clim. Past, 8, 877887, doi:10.5194/cp-8-877-2012, 2012.

Steffensen, J. P.: The size distribution of microparticles from selected segments of the Greenland Ice Core Project ice core representing different climatic periods, J. Geophys. Res., 102, 2675526763, 1997.

Steinhilber, F., Beer, J., and Fröhlich, C.: Total solar irradiance during the Holocene, Geophys. Res. Lett., 36, L19704, doi:10.1029/2009GL040142, 2009.

Sugden, D. E., McCulloch, R. D., Bory, A. J.-M., and Hein, A. S.: Influence of Patagonian glaciers on Antarctic dust deposition during the last glacial period, Nat. Geosci., 2, 281-285, doi:10.1038/NGEO474, 2009.

Takahashi, T., Sutherland, S. C., Sweeney, C., Poisson, A., Metzl, N., Tilbrook, B., Bates, N., Wanninkhof, R., Feely, R. A., Sabine, C., Olafsson, J., and Nojiri, Y.: Global sea-air $\mathrm{CO}_{2}$ flux based on climatological surface ocean $p \mathrm{CO}_{2}$, and seasonal biological and temperature effects, Deep-Sea Res. II, 49, 1601-1622, 2002.

Thompson, D. W. J. and Solomon, S.: Interpretation of Recent Southern Hemisphere Climate Change, Science, 296, 895-899, 2002.

Thompson, D. W. J., Solomon, S., Kushner, P. J., England, M. H., Grise, K. M., and Karoly, D. J.: Signatures of the Antarctic ozone hole in Southern Hemisphere surface climate change, Nat. Geosci., 4, 741-749, doi:10.1038/NGEO1296, 2011.

Thompson, L. G.: Variations in microparticle concentration, size distribution and elemental composition found in Camp Century, Greenland, and Byrd station, Antarctica deep ice cores, Isotopes and Impurities in Snow and Ice Symposium (Proceedings of the Grenoble Symposium), 351-364, 1977.

Toggweiler, J. R., Russell, J. L., and Carson, S. R.: Midlatitude westerlies, atmospheric $\mathrm{CO}_{2}$, and climate change during the ice ages, Paleoceanography, 21, PA2005, doi:10.1029/2005PA001154, 2006.

Turner, D. R. and Hunter, K. A. (Eds.): The Biogeochemistry of Iron in Seawater, John T. Wiley \& Sons, Ltd., Chichester, England, 2001.

Turner, J., Bindschadler, R. A., Convey, P., Di Prisco, G., Fahrbach, E., Gutt, J., Hodgson, D. A., Mayewski, P. A., and Summerhayes, C. P. (Eds.): Antarctic Climate Change and the Environment, Scientific Committee on Antarctic Research, Cambridge, 2009.
Vance, T., van Ommen, T. D., Curran, M. A. J., and Plummer, C. T.: A millennial proxy record of ENSO and eastern Australian rainfall from the Law Dome ice core, East Antarctica, J. Climate, 26, 710-725, doi:10.1175/JCLI-D-12-00003.1, 2013.

Varma, V., Prange, M., Lamy, F., Merkel, U., and Schulz, M.: Solarforced shifts of the Southern Hemisphere Westerlies during the Holocene, Clim. Past, 7, 339-347, doi:10.5194/cp-7-339-2011, 2011.

Varma, V., Prange, M., Merkel, U., Kleinen, T., Lohmann, G., Pfeiffer, M., Renssen, H., Wagner, A., Wagner, S., and Schulz, M.: Holocene evolution of the Southern Hemisphere westerly winds in transient simulations with global climate models, Clim. Past, 8, 391-402, doi:10.5194/cp-8-391-2012, 2012.

Wagenbach, D., Ducroz, F., Mulvaney, R., Keck, L., Minikin, A., Legrand, M., Hall, J. S., and Wolff, E.: Sea-salt aerosol in coastal Antarctic regions, J. Geophys. Res., 103, 10961-10974, 1998.

WAIS Divide Project Members, Fudge, T. J., Steig, E. J., Markle, B. R., Taylor, K. C., McConnell, J. R., Brook, E. J., Sowers, T., White, J. W. C., Schoenemann, S. W., Alley, R. B., Cheng, H., Clow, G. D., Cole-Dai, J., Conway, H., Cuffey, K. M., Edwards, J. S., Edwards, R. L., Edwards, R., Fegyveresi, J. M., Ferris, D. G., Fitzpatrick, J. J., Johnson, J., Hargreaves, G., Lee, J. E., maselli, O. J., Mason, W., McGwire, K. C., Mitchell, L. E., Mortensen, N., Neff, P., Orsi, A. J., Schauer, A. J., Severinghaus, J. P., Sigl, M., Spencer, M. K., Vaughn, B. H., Voigt, D. E., Waddington, E., Wang, X., and Wong, G. J.: Deglacial warming in West Antarctica driven by both local orbital and Northern Hemisphere forcing, Nature, 500, 440-444, doi:10.1038/nature12376, 2013.

Waugh, D. W., Primeau, F., DeVries, T., and Holzer, M.: Recent changes in the ventilation of the Southern Oceans, Science, 339, 568-570, doi:10.1126/science.1225411, 2013.

Wegner, A., Gabrielli, P., Wilhelms-Dick, D., Ruth, U., Kriews, M., De Deckker, P., Barbante, C., Cozzi, G., Delmonte, B., and Fischer, H.: Change in dust variability in the Atlantic sector of Antarctica at the end of the last deglaciation, Clim. Past, 8, 135147, doi:10.5194/cp-8-135-2012, 2012.

Wolff, E., Rankin, A. M., and Rothlisberger, R.: An ice core indicator of Antarctic sea ice production?, Geophys. Res. Lett., 30, 2158, doi:10.1029/2003GL018454, 2003.

Wolff, E. W., Rankin, A. M., and Rothlisberger, R.: Southern Ocean sea-ice extent, productivity and iron flux over the past eight glacial cycles, Nature, 440, 491-496, doi:10.1038/nature04614, 2006.

Wu, G., Yao, T., Xu, B., Tian, L., Zhang, C., and Zhang, X.: Volume-size distribution of microparticles in ice cores from the Tibetan Plateau, J. Glaciol., 55, 859-868, 2009.

Yan, H., Sun, L., Wang, Y., Huang, W., Qiu, S., and Yang, C.: A record of the Southern Oscillation Index for the past 2,000 years from precipitation proxies, Nat. Geosci., 4, 611-614, doi:10.1038/NGEO1231, 2011.

Yan, Y., Mayewski, P. A., Kang, S., and Meyerson, E.: An ice core proxy for Antarctic circumpolar zonal wind intensity, Ann. Glaciol., 41, 121-130, 2005. 